\author{
В.В. Завьялов ${ }^{1}$, Н.В. Завьялова ${ }^{1}$, В.И. Холстов ${ }^{1}$, \\ В.К. Гореленков ${ }^{2}$ Г.А. Фролов ${ }^{3}$, И.В. Лягин ${ }^{4}$, Е.Н. Ефременко 4
}

${ }^{1}$ Федеральное государственное бюджетное учреждение "27 Научный центр» Министерства обороны Российской Федерации, 105005, Российская Федерация, г. Москва, Бригадирский пер., д. 13

\author{
${ }^{2} \mathrm{OОO} \mathrm{«Научно-исследовательский} \mathrm{институт}$ \\ эластомерных материалов и изделий», Российская Федерация, \\ 111024, г. Москва, Перовский проезд, д. 2, стр. 1
}

${ }^{3}$ Национальный исследовательский технологический университет «МИСиС», Российская Федерация, 119049, г. Москва, Ленинский проспект, д. 4

${ }^{4}$ Московский государственный университет имени М.В. Ломоносова, химический факультет, 119991, Российская Федерация, г. Москва, Ленинские горы, д. 1, стр. 3

Поступила 04.08.2020 г. Принята к публикации 20.09.2020 г.

Целью представленного обзора является анализ существующих в литературе подходов к созданию и совершенствованию материалов и тканей на основе металлоорганических каркасных структур (МОК), которые могут быть базисом для разработки стратегии создания модульных МОК-материалов для современных средств индивидуальной защиты (СИЗ) от токсичных химикатов и патогенных микроорганизмов. В обзоре приводятся данные по использованию биомолекул для интеграции с МОК путем поровой инкапсуляции, поверхностного прикрепления, ковалентной связи, инкапсуляции in situ биомолекул в МОК и создание био-МОК. Представлены характеристики биомолекул, которые могут быть включены в МОК. Приводятся схемы включения некоторых биомолекул в состав МОК. Рассматриваются свойства МОК, обсуждаются направления их создания и перспективные направления применения композитов «биомолекулы-МОК». Излагается стратегия создания модульных МОК-материалов с заданными свойствами для современных СИЗ, которые будут обеспечивать защиту человека от различных поражающих факторов химической, биологической и физической природы. Приведены направления разработки современных СИЗ на основе модульных МОК-материалов с заданными свойствами. Предложены схемы создания отдельных модулей в структуре МОК, а также определения их важности и значения для придания МОК-материалу универсальных защитных свойств.

Ключевые слова: биомолекулы в металлорганических каркасах; зашитные материалы $u$ ткани; композиты «биомолекулы-МОК»; металлоорганические комплексы с заданными свойствами; металлоорганические комплексы; модульные МОК-материалы; специфические свойства - самоочищение (самодегазачия) и бактерииидность.

Библиографическое описание: Завьялов В.В., Завьялова Н.В., Холстов В.И., Гореленков В.К., Фролов Г.А., Ефременко Е.Н., Лягин И.В. Стратегия разработки современных средств защиты на основе металлоорганических комплексов с заданными свойствами // Вестник войск РХБ защичmbl. 2020. Т. 4. № 3. C. 305-337. https://doi.org/10.35825/2587-5728-2020-4-3-305-337 
Конвенция о запрещении разработки, производства, накопления и применения химического оружия и о его уничтожении (КЗХО) была принята Генеральной Ассамблеей ООН 30 ноября 1992 г. и вступила в силу 29 апреля 1997 г. Она позволила уничтожить химическое оружие как оружие массового поражения, но угрозы применения отравляющих веществ (OB) и токсичных химикатов (TX) в военных конфликтах и террористических актах сохранились. Это, в свою очередь, предопределяет необходимость совершенствования средств индивидуальной и коллективной защиты для вооруженных сил и гражданского населения.

Прогноз экипировки «солдата будущего» ведущих разработчиков таких средств на период до 2030 г. предусматривает защиту от ОВ, биологических агентов (БА) и ТХ в сочетании со специфическими свойствами - самоочищения (самодегазации) и бактерицидности материалов [1-4]. При этом большое внимание уделяется масштабному внедрению нанотехнологий в создание перспективных элементов экипировки солдат и защитных материалов различного назначения, которые могут быть использованы при выполнении задач химического производства, сельскохозяйственных работ, несения воинской службы и оказания медицинской помощи [5-7].

Совершенствование средств индивидуальной и коллективной защиты, повышающих боеспособность и выживаемость в условиях воздействия различных ТХ, исследователи связывают с технологиями получения металлоорганических каркасных структур или МОК [8]. МОК представляют собой соединения, состоящие из ионов металлов $\left(\mathrm{Zn}^{2+}, \mathrm{Cu}^{2+}, \mathrm{Cr}^{3+}, \mathrm{Al}^{3+}\right.$, $\mathrm{Fe}^{3+}$ и $\mathrm{Zr}^{4+}$ ) или кластеров, связанные между собой жесткими органическими молекулами так, что формируются одно-, двух- или трехмерные структуры, которые обладают порами разной величины [9-21]. Такие МОК лежат в основе создаваемых новых тканей для масок, защитных костюмов, фильтров, дегазаторов ОВ и дезинфекторов БА.

Как для МОК, так и для наночастиц различных металлов ( $\mathrm{Ag}, \mathrm{Mg}, \mathrm{Ni}, \mathrm{Ti}$ и др.), введенных в нановолокна, усиливающих дегазирующие свойства современных материалов в отношении ОВ и придающих им антимикробные свойства, большинство выявленных эффектов получено только в лабораторных условиях [22-39]. При внедрении этих разработок в реальные образцы средств индивидуальной защиты (СИЗ) возникает необходимость проведения дополнительных исследований процесса закрепления наночастиц на материалах, механизмов дегазации ОВ и дезинфекции БА.
Для создания совершенно нового классагибридных материалов используются различные подходы создания МОК с включенными биомолекулами, получившими название композитов «биомолекулы-МОК». За последнее время был разработан и синтезирован широкий спектр композитов «биомолекулы-МОК», которые сочетают в себе превосходные физические и химические свойства МОК (высокая пористость, настраиваемый размер пор и др.) с универсальными функциональными возможностями биомолекул, что позволяет использовать их также в биокатализе, зондировании, визуализации и доставке лекарственных средств к мишеням с заданными свойствами.

Цель работы - разработка стратегии создания металлоорганических комплексов (МОК) с заданными свойствами из модулей для современных средств защиты.

Разработка стратегии создания металлоорганических комплексов с заданными свойствами из модулей для современных средств защиты от токсичных химикатов и микроорганизмов основывалась на анализе существующих в литературе подходов создания и совершенствования материалов и тканей, содержащих МОК, данных о свойствах МOК и характеристиках биомолекул, подходах включения биомолекул в металлорганические каркасные структуры, свойствах и характеристиках композитов «биомолекулы-МОК» и достижениях применения композитов «биомолекул-МОК» в биокатализе, биосенсорике, доставке лекарств, визуализации клеток и разделении молекул.

1. Биомолекулы, включенные в металлоорганические каркасные структуры

Биомолекулы, которые исследователи включают в МОК, представляют собой как макромолекулы (белки, нуклеиновые кислоты, углеводы, липиды), так и низкомолекулярные вещества (аминокислоты, нуклеотиды, жирные кислоты, гликолипиды). Обычно это активные вещества растительного или животного происхождения, необходимые для поддержания жизнедеятельности организма. Они могут служить природными катализаторами, датчиками или участвовать в окислительно-восстановительных процессах [40]. Большинство биомолекул используются только в очень «мягких» условиях при сохранении всех функций в неестественных или сложных средах $[41,42]$.

Наиболее эффективный метод повышения их устойчивости - включение в защитную оболочку. По сравнению со свободным состоянием, биомолекулы, включенные в композиты, приобретают значительно более высокую термическую, химическую и даже механическую 
стабильность. Следовательно, резко расширяются их потенциальные возможности применения in vitro и in vivo [41-47].

Открытая еще в 1916 г. J. Nelson и E.G. Griffin иммобилизация биомолекул показала, что после физической адсорбции на уголь, фермент инвертаза сохраняет свою каталитическую активность [48]. Эти исследования заложили основу иммобилизации на твердых носителях различных видов биомолекул для широкого применения, обеспечивающих повышение их стабильности, легкость разделения и повторного использования при одновременной защите их от агрессивных сред [42-45, 49, 50].

Металлоорганические каркасы (комплексы) или МОК, известные как пористые координационные полимеры (ПКП) [51-56], представляют собой разновидность пористого кристаллического материала, построенного из координации органических лигандов и неорганических ионов металлов (или металлических кластеров). Упорядоченная и перестраиваемая пористость, хорошая кристалличность и высокая площадь поверхности МОК делают их отличной матрицей-хозяином для иммобилизации или включения в свою структуру «гостевых молекул» (биомолекул).

Металлические каркасы обладают следующими свойствами $[49,51,52]$ :

- высокая поверхностная площадь и пористость МОК обуславливают высокую возможность включения биомолекул;

- МОК - это открытые системы, поэтому субстраты и продукты, встроенные в МОК, могут транспортироваться из пор, а «гостевые молекулы» - взаимодействовать с внешней средой;

- металлические узлы, лиганды, а также сами структуры МОК обладают большим разнообразием, геометрия и свойства МОК могут быть спроектированы и адаптированы в соответствии с направлениями их применения;

- включенные в МОК биомолекулы способны взаимодействовать с различными активными группами, равномерно распределенными как в порах, так и на ее поверхности, при этом уменьшается или устраняется их вымывание;

- кристаллическая структура МОК имеет большое значение при исследовании механизмов взаимодействия с «гостевыми» молекулами.

Благодаря этим уникальным свойствам МОК могут быть использованы в качестве матриц для включения биомолекул в рамках реализации технологий по созданию нового класса гибридных материалов. Созданные композиты «биомолекулы-МОК» сочетают свойства обоих компонентов, поэтому считается, что МОК и биомолекулы взаимодополняют друг друга.

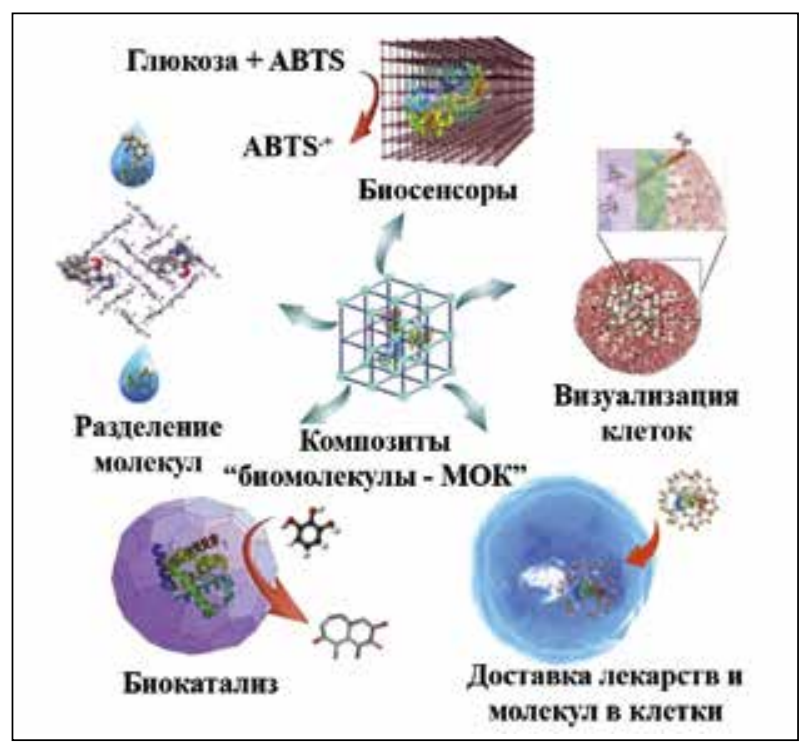
Рисунок 1 - Схема возможного применения
композитов «биомолекулы-МОК» [8]

МОК не только создают стабилизирующее микроокружение для улучшения работы биомолекул, но и способствуют восстановлению и повторному использованию биомолекул, а также выведению их из конструкций при необходимости. Кроме того, гетерогенное свойство МOK облегчает применение биомолекул в различных областях, таких как катализ, сенсоры и разделение молекул (рисунок 1).

С другой стороны, иммобилизованные биомолекулы функционализируют композиты «биомолекулы-МОК» и придают им новые свойства, что значительно расширяет возможности применения МОК в различных технологиях, особенно в областях биокатализа и биомедицины [56-60].

Таким образом, МОК и биомолекулы в гибридных материалах являются взаимодополняющими и незаменимыми, а включение биомолекул в МОК расширяет возможности их применения. Как показал проведенный анализ данных литературы, биомолекулы от нуклеиновых кислот до ферментов, имеющие различные размеры, успешно были включены в MOK с использованием различных подходов, таких как: поровая инкапсуляция, поверхностное прикрепление, использование полярной ковалентной связи, in situ инкапсуляция, био-МОК $[49,61-63]$.

2. Подходы включения биомолекул в металлоорганические каркасные структуры

Химические и структурные особенности МОК, такие как высокая кристалличность, большая поверхностная площадь, большой объем пор и большое структурное разнообразие, наделяют их огромными возмож- 


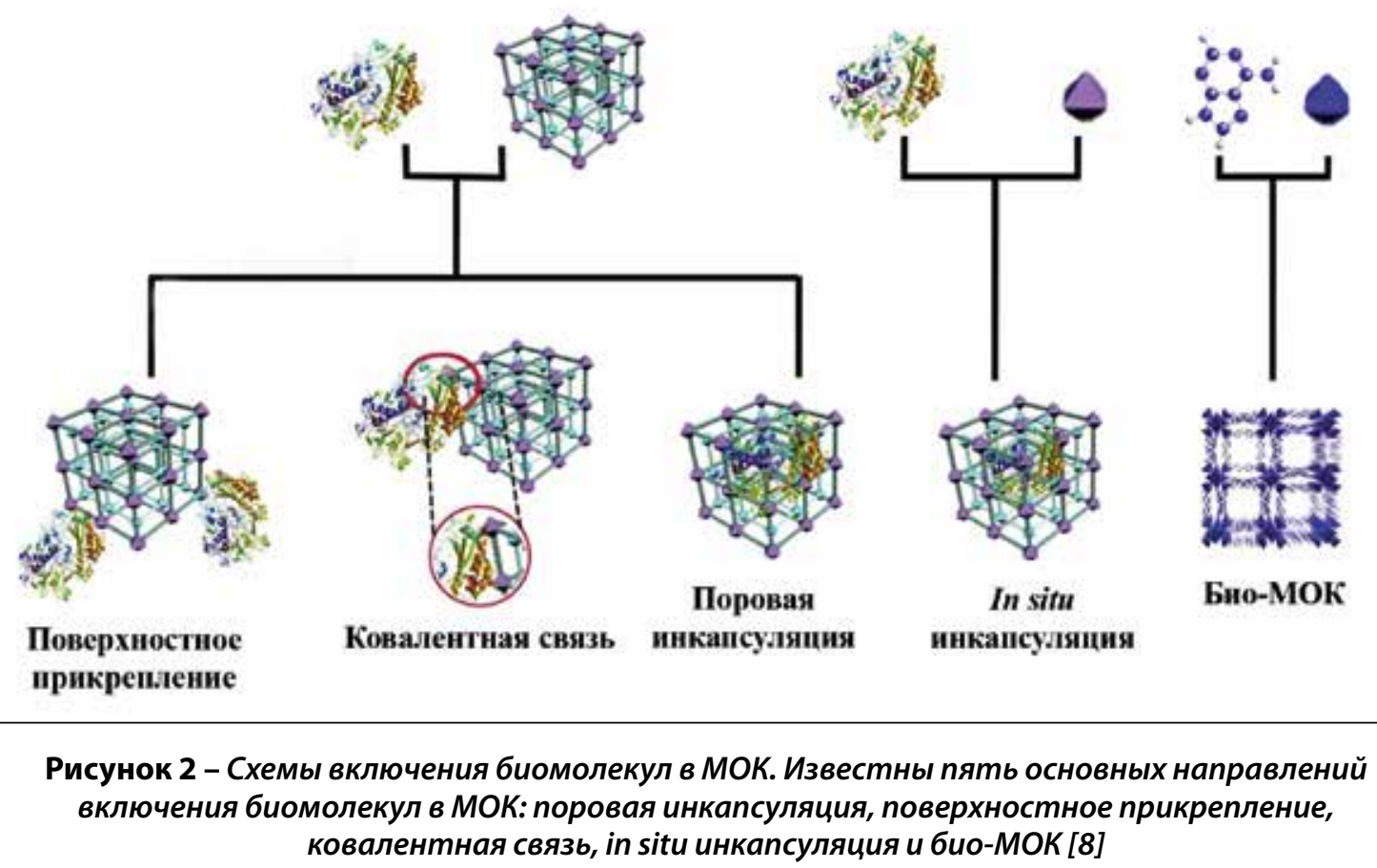

ностями в процессах адсорбции или улавливания биомолекул как внутри пор, так и на их внешней поверхности $[49,58,61-67]$.

Многие виды биомолекул, такие как ферменты [68-74], антитела [75-77], пептиды [78-80] и нуклеиновые кислоты [81-84], были успешно включены в МОК. На их основе были созданы новые композиты «биомолекулы-МОК», которые нашли свое применение в таких направлениях как биокатализ, биосенсоры, биотопливные клетки и биоэлектронные устройства.

В состав МОК биомолекулы могут быть включены по следующим схемам: MOK;

- сорбция (включение) биомолекул в поры

- адгезия биомолекул на внешней поверхности кристаллов МOK;

- инкапсуляция биомолекул in situ в кристаллы MOK, как «дефект кристалла»;

- непосредственное использование биомолекул в качестве лигандов для синтеза МOK.

На рисунке 2 приведены схемы включения биомолекул в состав МОК.

Доминирующими силами объединения для первых двух схем являются Ван-дер-Ваальсовое взаимодействие, $\pi-\pi$ взаимодействие или водородная связь. Что касается ковалентной связи, то она основана на химических связях между биомолекулами и МОК.

В таблице 1 приведена информация, имеющаяся в литературе, о направлениях включения биомолекул в МОК и полученных композитах «биомолекулы-МОК».

Поровая инкапсуляция. Размеры пор МОК можно регулировать от ультра-микропо- ристого до мезопористого размера (>2 нм), поэтому они могут вмещать в себя многие типы биомолекул разных размеров.

Так как поровая инкапсуляция является наиболее простым и широко используемым методом включения биомолекул в МОК [72-74, 85-95], это направление широко используется для введения биомолекул в их структуру. Поскольку синтез МОК обычно происходит в жестких условиях (например, высокая температура, органические растворители), этот метод модификации МОК может включать биомолекулы в «мягких» условиях и не влиять на их структуру и активность. Кроме того, поры МОК обеспечивают окружающую среду для биомолекул и препятствуют их агрегации и дополнительно ограничивают влияние факторов денатурации.

В последние годы, помимо микропористых МОК, были описаны и мезопористые MOK, открывающие новые возможности для иммобилизации крупных биомолекул. Некоторые МОК имеют разнообразные иерархические поры, которые способны избирательно улавливать различные виды субстратов, ферментов или кофакторов, и считаются перспективными для использования $[63,69,74,96]$.

При поровой инкапсуляции важны как МОК с хорошей водостойкостью, так и соответствующие размеры этих входных пор для биомолекул. Исследования показали, что трехмерные (3D) MOK более предпочтительны, поскольку их относительно небольшие поры способны улавливать разнообразные биомолекулы [97]. В ходе этого процесса биомоле- 
Strategy for Development of Modern Protective Equipment Based on Organometallic Complexes with Desired Properties

Таблица 1 - Направления включения биомолекул в металлоорганические конструкции [8]

\begin{tabular}{|c|c|c|c|c|}
\hline № ח/п & $\begin{array}{c}\text { Направления включения } \\
\text { биомолекул в МОК }\end{array}$ & MOK & Биомолекулы & Источник \\
\hline 1 & Поровая инкапсуляция & Ть-мезоМОК & МП-11 & 72 \\
\hline 2 & Поровая инкапсуляция & Ть-мезоМОК & цитохром C & 98 \\
\hline 3 & Поровая инкапсуляция & PCN-333 & ПРХ, МП-11, цитохром С & 73 \\
\hline 4 & Поровая инкапсуляция & PCN-128y & КОФГ & 88 \\
\hline 5 & Поровая инкапсуляция & PCN-888 & ГОк, ПРХ & 69 \\
\hline 6 & Поровая инкапсуляция & PCN-333 & Тирозиназа & 70 \\
\hline 7 & Поровая инкапсуляция & PCN-333 & СОД, КАТ & 74 \\
\hline 8 & Поровая инкапсуляция & Cu-MOK & МП-11 & 90 \\
\hline 9 & Поровая инкапсуляция & Mn-MOK & цитохром C & 91 \\
\hline 10 & Поровая инкапсуляция & PCN-333 & $\Pi \mathrm{ПX}$ & 92 \\
\hline 11 & Поровая инкапсуляция & IR-MOK-74-Y & витамин В ${ }_{12}$, МОП-18 & 93 \\
\hline 12 & Поровая инкапсуляция & Тb-мезоМОК & Миоглобин & 94 \\
\hline 13 & Поровая инкапсуляция & POST-66(Y) & $\begin{array}{c}\text { Витамин } \mathrm{B}_{12} \text {, цитохром C, } \\
\text { миоглобин, ПРХ }\end{array}$ & 95 \\
\hline 14 & Поверхностное прикрепление & Cu-MOK & МП-11 & 90 \\
\hline 15 & Поверхностное прикрепление & ZIF-70 & гдг & 102 \\
\hline 16 & Поверхностное прикрепление & ZIF-8 & Цитохром C & 103 \\
\hline 17 & Поверхностное прикрепление & $\begin{array}{c}\text { MIL-101(Cr), MIL- } \\
\text { 100(Cr), UiO-66(Zr), } \\
\text { CYCU-4(AI) }\end{array}$ & Трипсин & 100 \\
\hline 18 & Поверхностное прикрепление & Cu-BTC & Bacillus subtilis липаза & 106 \\
\hline 19 & Поверхностное прикрепление & ZIF-8 & Лизозим & 107 \\
\hline 20 & Поверхностное прикрепление & ZIF-8 & Карбоксиангидролаза & 104 \\
\hline 21 & Поверхностное прикрепление & $\begin{array}{c}\text { UiO-66, UiO-66- } \\
\text { NH2(Zr), MIL-53(Al), } \\
\text { карбонизованный } \\
\text { MIL-53(Al) }\end{array}$ & $\begin{array}{c}\text { Липаза из панкреатиче- } \\
\text { ской железы свиньи }\end{array}$ & 101 \\
\hline 22 & Ковалентная связь & MIL-100(Fe) & Лакказа & 118 \\
\hline 23 & Ковалентная связь & $\mathrm{UiO}-66-\mathrm{NH} 2$ & Соевая эпоксидгидролаза & 119 \\
\hline 24 & Ковалентная связь & NH2-MIL-53(Al) & $\beta$-глюкозидаза & 120 \\
\hline 25 & Ковалентная связь & MIL-100(Fe) & ГОк & 71 \\
\hline 26 & Ковалентная связь & IRMOK-3 GFP & Липаза & 111 \\
\hline 27 & Ковалентная связь & $\begin{array}{l}\text { NH2-MOFs, } \\
\text { MIL53(Al), NH2- } \\
\text { MIL101(Cr) }\end{array}$ & ГОк & 112 \\
\hline
\end{tabular}




\begin{tabular}{|c|c|c|c|c|}
\hline № $\pi / n$ & $\begin{array}{c}\text { Направления включения } \\
\text { биомолекул в МОК }\end{array}$ & MOK & Биомолекулы & Источник \\
\hline 28 & Ковалентная связь & MIL-88B(Cr)-NH2 & Трипсин & 113 \\
\hline 29 & Ковалентная связь & MOK-5 & анти-БСА & 139 \\
\hline 30 & Ковалентная связь & UiO-66-N3 & ДНК & 81 \\
\hline 31 & In situ инкапсулирование & ZIF-8 & Гемин, ГОк & 123 \\
\hline 32 & In situ инкапсулирование & ZIF-8 & KAT & 124 \\
\hline 33 & In situ инкапсулирование & ZIF-8 & ГОк, ПРХ & 125 \\
\hline 34 & In situ инкапсулирование & ZIF-8 & ГОк & 126 \\
\hline 35 & In situ инкапсулирование & ZIF-8 & цитохром C & 129 \\
\hline 36 & In situ инкапсулирование & ZIF-90 & KAT & 130 \\
\hline 37 & In situ инкапсулирование & ZIF-90 & KAT & 127 \\
\hline 38 & Био-МОК & Bio-MOK, bMOK & Аденин & 138 \\
\hline 39 & Био-МОК & PCN-530 & Аденин, тимин & 143 \\
\hline 40 & Био-МОК & [Zn(Gly-Ala)2] & Пептид & 145 \\
\hline 41 & Био-МОК & ZnCar & Пептид & 146 \\
\hline \multicolumn{5}{|c|}{$\begin{array}{l}\text { Примечания. } \\
\text { МП-11 - микропероксидаза 11; ПРХ - пероксидаза хрена; КОФГ - кислая органофосфатангидролаза; } \\
\text { ГОк - глюкозооксидаза; СОД - супероксиддисмутаза; КАТ - каталаза; ГДГ - глюкозо-6-фосфатдегидрогеназа; } \\
\text { БСА - бычий сывороточный альбумин; ДНК - дезоксирибонуклеиновая кислота. }\end{array}$} \\
\hline
\end{tabular}

кулы проникают в поры МОК и изменяют свою форму, приобретая отличия от нативной или денатурированной формы [98]. Следовательно, поровую инкапсуляцию можно рассматривать как универсальный и эффективный способ включения биомолекул (например, фермента) в МOK.

В 2011 г. впервые успешно была иммобилизована микропероксидаза-11 (МП-11) в мезопористые Тb-мезоМОК, которые обладали иерархическими полостями диаметром от 3,9 до 4,7 нм. Установлено, что инкапсулированный в такие МОК фермент может сохранять свою активность или проявлять более высокую активность, чем инкапсулированный в мезопористый кремнезем [72].

Изучение механизма процесса инкапсуляции показало, что цитохром С, который имеет молекулярный размер 2,6 нм × 3,2 нм $\times$ 3,3 нм, может быть захвачен Тb-мезоМОК, размеры пор которого (1,3 нм и 1,7 нм) гораздо меньше, чем захваченный белок. Это явление было объяснено таким свойством белка, как гибкость. При исследовании транслокации молекулы цитохрома С во внутреннюю часть
МОК через относительно небольшие поры, авторы [98] предположили, что биомолекулы претерпевают значительные конформационные изменения. Это предположение было подтверждено флуоресцентным анализом [98]. Цитируемая работа заложила теоретическую основу для раскрытия и понимания сложных процессов транслокации биомолекул.

B работе D. Feng с соавт. [73] показано получение мезопористых МОК, включая PCN-333 и PCN-332, обладающих высокой водостойкостью и многогранностью. В будущем эти МОК, защищающие биомолекулы от агрегации и выщелачивания, могут быть использованы в качестве одномолекулярных ловушек (ОМЛ) для ферментов. Авторами показано, что после иммобилизации каталитическая активность ферментов сохраняется, а каталитические свойства значительно улучшаются [73].

Созданный иерархический мезопористый MOK РCN-888 содержал три типа пор с различными размерами $(2 \mathrm{Hм} \times 5$ нм $\times 6,2 \mathrm{Hм})$, соединял два фермента в тандеме с точным контролем распределения каждого фермента. Самая большая пора (размером 6,2 нм) может 
быть использована в качестве ОМЛ глюкозооксидазы (ГОк), промежуточная пора (размером 5,0 нм) использовалась в качестве ОМЛ пероксидазы хрена (ПРХ), а небольшая пора (размером 2,0 нм) могла обеспечить диффузию субстратов. Полученный такой нанореактор показал высокую каталитическую эффективность, хорошую циклическую производительность и стабильность против переваривания трипсина, благодаря защитному эффекту МOK PCN-888 [69].

На основе этого исследования позже была разработана и предложена нанофабрика путем соединения супероксиддисмутазы (СОД) и каталазы (КАТ) в МОК РCN-333. Поскольку МOK PCN-333 был стабилен в сложной среде и имел хорошую биосовместимость, авторы далее исследовали активность SC@FNPCN-333. Полученные результаты показали, что изученный гибридный материал может защитить клетки человека от токсичных активных форм кислорода в течение одной недели. Таким образом они продемонстрировали потенциальные биотехнологические возможности применения композита «биомолекулы-МОК» [74].

В ряде работ для инкапсуляции биомолекул, помимо МОК с многогранными порами, были также использованы МОК с мезопористыми канальными структурами. При этом размер и гидрофильность пор оказывали влияние на процесс адсорбции [88, 90, 93].

В 2012 г. была получена серия аналогов МOK-74 с диаметром пор в диапазоне от 1,4 до 9,8 нм путем изменения длины лиганда. Крупные молекулы, такие как витамин $\mathrm{B}_{12}$, металлорганический многогранник-18, миоглобин и зеленый флуоресцентный белок (ЗФБ), были иммобилизованы в порах этих МОК [93]. В работе Z. Zhong с соавт. приведены данные по созданию мезопористого Cu-MOК с диаметром пор 15,2-20,7 нм, который может иммобилизовать лакказу [89].

В литературе имеются данные по инкапсулированию кислой органофостфатангидролазы (КОФГ) в МОК РCN-128у с размером пор 4,4 нм. Показано значительное повышение стабильности этого фермента после иммобилизации [88].

Мезопористый MOK NU-1000 с иерархическими порами может быть использован в качестве твердой основы для инкапсуляции, защиты и доставки фермента [96]. Используя аналогичный метод, были получены серии МОК NU-100 с мезопористыми каналами в диапазоне от 3,3 до 6,7 нм. Такая структура может быть использована для иммобилизации фермента большего размера, а также для кофермента, имеющего небольшой размер. Мезопористые каналы обеспечивают диффузию субстратов и, таким образом, повышают реакционную активность как фермента, так и кофермента [85].

Поверхностное прикрепление. Помимо поровой инкапсуляции, другим направлением получения композитов «биомолекулы-МОК» стало поверхностное прикрепление [90,99-108]. Этот метод не имеет строгих требований к размеру пор МOK, и процесс иммобилизации проходит обычно быстрее и проще по сравнению с другими методами объединения биомолекул с МОК. Однако проблемой такого метода получения композитов является вымывание биомолекул и ослабление защитного эффекта МОК.

В 2006 г. была исследована иммобилизация пероксидазы МП-11 в МОК, созданного на основе $\mathrm{Cu}$, а также пяти мезопористых кремнийорганических веществ [90]. Результаты показали, что пероксидаза сохраняла активность после иммобилизации. Аналогичным образом была разработана серия кристаллических микропористых МОК для иммобилизации ферментов без какой-либо химической модификации поверхности МОК или ферментов. Водородная связь и $\pi-\pi$ взаимодействие в основном способствовали притяжению по типу «хозяин-гость» между ферментами и органическими линкерами в МОК $[99,100]$. Биореактор показал большой потенциал возможного его применения во многих областях, особенно в катализе и протеомике [101].

W. Ма с соавт. показали возможность получения интегрированного электрохимического биосенсора с использованием цеолитных имидазолатных каркасов (ZIF) в качестве матрицы для коиммобилизации метиленового зеленого (M3) и глюкозодегидрогеназы (ГДГ) [102].

C. Zhang с соавт. смогли прикрепить цитохром C на поверхность MOK ZIF-8. Активность цитохрома С при этом увеличилась на 128 \%, и улучшилось видимое сродство к субстрату по сравнению с нативным цитохромом C [103].

B работе G.-H. Qiu с соавт. представлены результаты успешного синтеза и характеристики влагостойкости и водостойкости трехмерного (3D) MOK на основе цвиттерионного карбоксилатного лиганда (N-карбоксиметил-(3,5-дикарбоксил)-пиридиний бромида $(\mathrm{H} 3 \mathrm{CmdcpBr}))$, который может образовывать электростатические и водородные связующие взаимодействия с одноцепочечной ДНК [83].

Ковалентная связь. Несмотря на то что различные биомолекулы были успешно иммобилизованы в МОК путем физической адсорбции, относительно слабые взаимодействия между биомолекулами и МОК приводили к медленному их вымыванию. Чтобы избежать вымывания биомолекул, был разработан метод иммобилизации (включения) биомо- 
лекул в МОК через ковалентную связь [79, 81, 109-117].

Показано существование многих нуклеофилов, таких как аминогруппа, карбоксильная группа, фенольная группа, тиольная группа, имидазольная группа, индольная группа и гидроксильная группа в биомолекулах, которые могут образовывать ковалентные взаимодействия с органическими линкерами в МОК. Установлено, что на поверхности кристаллов МОК существует большое разнообразие функциональных групп (например, свободных карбоксильных и гидроксильных групп, аминогрупп), которые способны соединяться с реактивными группами биомолекул. Установлено, что биомолекулы ковалентно связываются с МОК тремя способами:

1) биомолекулы сшиваются линкерными молекулами, такими как глутаровый альдегид, и образуют при этом самосборный монослой (ССМ) на поверхности МОК;

2) биомолекулы непосредственно связываются с активными группами МОК через ковалентные связи;

3) биомолекулы предварительно ковалентно конъюгируют с органическими лигандами и затем образуют МОК в процессе самосборки.

Перекрестное ковалентное связывание биомолекул с МОК было разработано несколькими группами исследователей, которые попытались последовательно связать биомолекулы со сшивающими агентами, такими как глутаровый альдегид [71, 118-120]. Используя этот метод, впервые были созданы МОК-пленки на SU-8 с биопрепаратом $\beta$-глюкозидазы [120]. Аналогичным образом был изготовлен биоэлектрод ГОк-MIL-100(Fe)-PtNP для обнаружения глюкозы путем иммобилизации глюкозооксидазы (ГОк) на MOK (т. е. MIL-100 (M), $\mathrm{M}=\mathrm{Fe}, \mathrm{Al}, \mathrm{Cr})$ и азобензентетракарбоксилат железа(III) MIL-127 (Fe).

Сравнение параметров различных биосенсоров на основе МОК показало, что МОК на основе железа проявляют лучшие свойства по сравнению с другими неорганическими матрицами для иммобилизации ферментов [71]. Была успешно проведена иммобилизация 2,20-азино-бис (3-этилбензотиазолин-6-сульфокислоты) и фермента лакказы на MIL-100(Fe) путем воздействия на биоэлектрод насыщенными парами глутарового альдегида [118].

Y. Zhang с соавт. создали биокатализатор, основанный на иммобилизации трипсина на ДЦК-активном МОК [114]. S.-L. Сао с соавт., используя глутаровый альдегид (ГА) для сшивания соевой эпоксидгидролазы с $\mathrm{MOK} \mathrm{UiO}-$ 66-NH2, получили новую нано-микро-биокаталитическую систему [119].
Способ получения композитов «биомолекулы-МОК» с помощью ковалентных связей широко представлен в литературе. До сих пор большинство исследований в этом направлении проводилось на поверхности МОК. Очень важным в этом направлении считается активация поверхности МОК до взаимодействия с биомолекулами. Активные группы, такие как аминогруппы и карбоксилатные группы, обычно использовались для осуществления процесса иммобилизации с помощью реакций основания Шиффа, реакций кликхимии или хемосорбции. Что касается постсинтетической модификации МОК, то можно отметить ряд новаторских работ в этом направлении по включению биомолекул в МОК через ковалентные связи [115]. Был специально разработан метод, в котором использовались связывающие группы МОК. После образования МОК открытые карбоксилатные группы в органических линкерах активировали 1-этил-3-(3-диметиламинопропил) карбодиимидом (ЭДАП) или дициклогексилкарбодиимидом (ДЦК). Активированные карбоксилаты конъюгировали со многими биомолекулами. При этом МОК далее был успешно конъюгирован с улучшенным зеленым флуоресцентным белком (EGFP), используя ЭДАП для активации свободных карбоксилатных групп МОК. Проведенные ИК-спектрометрия, флуоресцентная микроскопия, твердотельная люминесценция, а также конфокально-лазерно-сканирующая микроскопия подтвердили изменение поверхности МOK [111].

Установлено, что, используя метод постсинтетической модификации, авторам удалось иммобилизовать глюкозооксидазы на двух амино-МОК [112]. Этот метод впоследствии был использован для иммобилизации многих видов биомолекул $[114,116]$.

Реакции клик-химии также могут использоваться для иммобилизации биомолекул. Впервые реакции клик-химии применили при синтезе конъюгатов наночастиц композита «нуклеиновая кислота-МОК» на основе реакции между N3 и дибензилциклооктином (ДБЦО). Для реакции функционализированной ДНК с ДБЦО использовали предварительно синтезированные наночастицы UiO-66-N3 [81]. После этой реакции структура МОК была сохранена. ДНК была иммобилизована на поверхности МОК, так как размер пор UiO-66 слишком мал, чтобы вместить ДНК. Кроме того, в этой работе была изучена коллоидная стабильность и возможность клеточной трансфекции этого композита «ДНК-МОК». Результаты показали, что такой композит обладает повышенной стабильностью и улучшенным поглощением пор по сравнению с недекорированными частицами МОК. 
D. Fujita с соавт. с помощью процесса самосборки впервые сконструировали МОК вокруг ковалентно связанного белка. Небольшой белок, убиквитин, присоединили к одному бидентатному лиганду. После добавления ионов $\mathrm{Pd}$ (II) (M) и лигандов (L) координационные нанокластеры M12L24 самособрались вокруг белка. Результаты этого исследования стали важной вехой в проведении контроля инкапсулированных белков [117].

In situ инкапсуляция. Хотя доказано, что поверхностная адсорбция, инкапсуляция пор и ковалентная связь являются эффективными подходами к объединению биомолекул, эти направления имеют определенные ограничения в применении, особенно для объединения биомолекул, имеющих большие размеры.

В последние несколько лет in situ инкапсуляция стала наиболее распространенным подходом для объединения биомолекул с МОК. МОК растут вокруг биомолекул, что приводит к высокой эффективности включения биомолекул в поры и к почти полному отсутствию их вымывания. Нуклеация и иммобилизация происходят одновременно.

Такая in situ инкапсуляция биомолекул в МОК имеет много преимуществ перед обычной сорбцией. Одним из очевидных преимуществ является отсутствие каких-то ограничений по размеру биомолекул. Таким способом можно инкапсулировать широкий спектр и различные типы биомолекул с высокой эффективностью включения их в процессе формирования МОК. При этом биомолекулы равномерно распределяются внутри МОК без вымывания. Этот быстрый и недорогой метод значительно облегчает применение биомолекул во многих областях.

Однако стратегия in situ инкапсуляции проводится только в мягких условиях в водных растворах, поскольку большинство биомолекул не могут выжить в агрессивных синтетических условиях, таких как высокая температура и органические растворители, что значительно ограничивает число таких МОК для практического использования [121-130].

F. Lуu с соавт., используя метод совместного осаждения, внедрили цитохром С в МОК ZIF-8. При этом определенное количество поливинилпирролидона, который использовался для поддержания дисперсии и для стабилизации белка, предварительно был смешан с ферментом перед добавлением гексагидрата нитрата цинка [129]. Эта работа, несомненно, открыла новый путь к простому и быстрому получению гибридных материалов «биомолекулы-МОК». Основываясь на этом методе, были включены мультиферменты - глюкозооксидаза (ГОк) и пероксидаза хрена (ПРХ) в MOK ZIF-8 путем одноэтапного поверхност- ного синтеза [125]. Полученный гибридный материал показал высокую чувствительность, селективность, а также стабильность при длительном хранении.

Поскольку многокомпонентная система является перспективной для широкого использования (промышленного биокатализа, фармацевтики и биомедицинских устройств), разработанная in situ инкапсуляция открыла новые возможности для подготовки и применения в разных областях получаемых гибридных материалов.

Опираясь на выше изложенные результаты исследований, Т.-Т. Chen c соавт. иммобилизовали белок в наночастицы ZIF-8 для создания новой системы, которую можно использовать в качестве эффективной платформы для доставки и эндолизосомального высвобождения активных белков в живых клетках [131]. В дальнейшем H. Cheng с соавт. выполнено инкапсулирование глюкозооксидазы в наночастицы ZIF-8 с помощью метода совместного осаждения для определения глюкозы в условиях in vivo [123]. Значительный вклад в процесс изучения in situ инкапсуляции внесли ученые, опубликовав результаты своих исследований в ряде работ [132-134].

Вдохновленные естественными процессами биоминерализации, исследователи предположили, что МОК могут выступать в качестве защитных покрытий для биомакромолекул путем инкапсуляции de novo [128]. Авторы этой работы изучили не только биомакромолекулы (белки, ДНК и ферменты), но и различные MOK (ZIF-8, HKUST-1, E-Tb-BDC и MIL-88A). Полученные результаты показали, что ферменты способны сохранять свою активность даже в неблагоприятных условиях после инкапсуляции. Кроме того, исследователи предположили, что существуют некоторые взаимодействия между прекурсорами МОК и биомакромолекулами, которые способствуют образованию МОК вокруг биомакромолекул.

S.L. Anderson и K.C. Stylianou успешно инкапсулировали вирус табачной мозаики (BTM) внутрь MOK ZIF-8 и создали бионаночастицу BTM@ZIF-8 в форме стержневидной сердцевины-оболочки с перестраиваемой толщиной оболочки. Ими показано, что метод инкапсуляции de novo может быть применен для захвата достаточно больших биомолекул. Впоследствии ученые провели всестороннее исследование и выяснили механистические основы процесса биомиметической минерализации сердцевины-оболочки с помощью ZIF-8 на ВТМ. Они обнаружили, что параметры кристаллизации ZIF-8 значительно влияют на окончательную морфологию BTM@ZIF-8, и что взаимодействие BTM-Zn, а не заряд играет 
ключевую роль в этом процессе минерализации [58]. Было также установлено, что ZIF-8 может расти на поверхности белка, покрытого полиэтиленгликолем [135]. Эта результаты еще больше расширили возможности применение de novo инкапсуляции, а связанные с ней исследования механизмов стали руководством для разработки минерализации МОК на белковых материалах.

F.-K. Shieh c соавт. показали, что MOKZIF-90 также является хорошим объектом для иммобилизации биомолекул с помощью этого подхода. При проведении углубленных исследований были внедрены молекулы каталазы в MOK ZIF-90 методом de novo инкапсуляции и продемонстрирована универсальность этого метода [127].

До настоящего времени для инкапсуляции биомолекул in situ использовались MOK ZIF-8 и MOK ZIF-90 [121-130], которые подготавливались в мягких биосовместимых условиях. Ограниченные размеры пор МОК (например, ZIF-8, ZIF-90 и MIL-88A) препятствовали широкому применению этого подхода в биокатализе и зондировании, поскольку субстраты не в состоянии диффундировать в маленькие поры для контакта с инкапсулированными ферментами. Поэтому для дальнейшего продвижения in situ инкапсуляции необходимо было создание большего количества новых структур МОК, которые могли бы адаптироваться к мягким синтетическим условиям.

Био-МОК. Такие биомолекулы, как аминокислоты, пептиды, нуклеотидные основания и сахариды обладают химически активными группами в своих структурах. Эти группы хорошо координируют с различными металлами и выступают в качестве органических линкеров для синтеза МОК $[59,136]$. Использование биомолекул в качестве лигандов для координации с металлами помогло сформировать новый тип МOK, который назвали био-МОК. Био-МОК склонны к лучшей биосовместимости и обеспечивают особую функциональность [137, 138]. Из-за недостатка симметрии, а также высокой гибкости этих биомолекул трудно получить высококачественные кристаллы для био-МОК. Для того, чтобы создать био-МОК, требуется провести отбор высокосимметричных биомолекул или ввести симметричный колиганд. Установлено, что нуклеиновые азотистые основания, аминокислоты, пептиды и даже белки способны к построению био-МОК.

Наиболее широко изученными соединениями для конструирования био-МОК являются азотистые основания, так как они широко распространены в природе, имеют низкую стоимость и могут быть легко синтезированы. Кроме того, каждое азотистое основание имеет несколько доступных одиночных пар азота и кислорода, которые склонны координироваться с ионами металла.

Как правило, в этом методе предпочтительны азотистые основания с высокосимметричной структурой $[139,140]$. Аденин содержит пять атомов азота, пуриновое кольцо с четырьмя азотами и экзоциклическую аминогруппу $[138,139,141]$ и может служить отличным компонентом для координации с металлами или металлическими кластерами для создания био-МОК. Применяя смешанную лигандную методику путем введения бифенилдикарбоновой кислоты в реакцию между аденином и ацетатдигидратиндиметилформамидом цинка (ДМФ), был получен монокристаллический материал $\mathrm{Zn} 8(\mathrm{ad}) 4$ (BPDC) $6 \mathrm{O} \times 2 \mathrm{Me} 2 \mathrm{NH} 2 \times 8 \mathrm{DMF} \times 11 \mathrm{H} 2 \mathrm{O}$, био-МОК-1, который является самым ранним аденин-инкорпорированным МОК со значительной пористостью [141]. Используя цинкаденин-кластеры в качестве вершин для координации с молекулами дикарбоксилатного линкера, был получен новый вид пористого материала, названный био-МОК-100 [142]. Позднее, для преодоления недостатков низкой симметрии нуклеиновых оснований, для построения нового био-МОК был внедрен высокосимметричный линкер [143].

В качестве органических лигандов для построения МОК использовались аминокислоты, что обусловлено их многочисленными координационными группами, включая карбоксилаты и аминогруппы. Был разработан комплекс под названием [Hg12(ala)8( $\left.\left.\mathrm{NO}_{3}\right) 8\right] \times 2 \mathrm{H}_{2} \mathrm{O}$ путем простого одновременного смешивания нитрата ртути с L- или D-аланином [144]. В качестве органических линкеров для построения MOK использовался дипептид $[145,146]$. На основе дипептида карнозина ( $\beta$-аланил-L-гистидина) и Zn2+ был создан пористый 3D ZnCar-каркас. Этот вид каркаса показал постоянную микропористость и сильное адсорбционное сродство к СО2 и СН4 [146]. Исследователи экспериментально показали, что если пептид проявляет низкоэнергетические кручения и смещения, в таких случаях доступный объем пор может увеличиваться [145].

\section{3. Применение композитов «биомолеку-} лы-МОК»

Композиты «биомолекулы-МОК» объединяют свойства и характеристики обоих компонентов (биомолекул и материалов МОК), которые наделяют их разнообразными функциональными возможностями и отличными характеристиками, позволяющими использовать их во многих областях. Как уже отмечалось ранее, в последние несколько десятилетий 


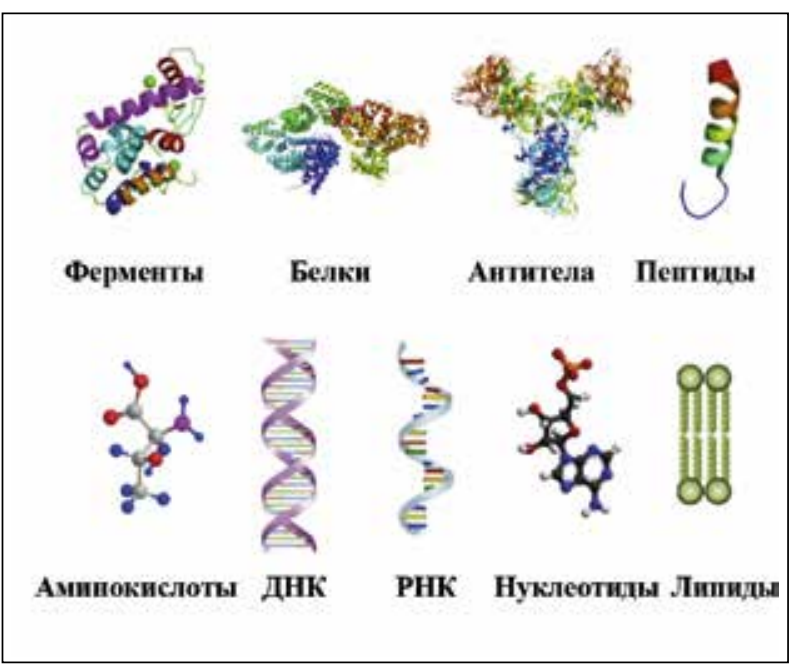

\section{Рисунок 3 - Схема биомолекул, которые могут быть включены в МОК для дальнейшего применения композитов «биомолекулы-МОК» [8]}

были зарегистрированы МОК с размерами пор от микропористых до мезопористых. Биомолекулы, от нуклеиновых кислот до ферментов, были успешно иммобилизованы в МОК с помощью различных методов $[41,42]$. На рисунке 3 представлены биомолекулы, которые успешно были включены в МОК для создания на их основе композитов «биомолекулы-МОК».

Наибольшие достижения в применении композитов «биомолекул-МОК» были достигнуты в биокатализе, биосенсорике, доставке лекарств, визуализации клеток и разделении молекул. В таблице 2 представлены некоторые области применения композитов «биомолекулы-МОК».

Биокатализ. Ферменты хорошо известны как высокоэффективные природные катализаторы. Однако хрупкая природа ферментов и такие их свойства, как узкий диапазон рН-толерантности, низкая термическая стабильность и низкая устойчивость к органическим растворителям препятствовали их практическому применению. Исходя из структурных и химических свойств, МОК подходят для использования в качестве матриц-хозяев при иммобилизации (включения) в них ферментов $[60,147]$. Композиты «фермент-МОК» были использованы в качестве новых платформ для гетерогенного биокатализа и показали ряд преимуществ, включая высокую стабильность и многократное использование, легкость разделения продуктов и лучшую каталитическую селективность.

Гемопротеины (пероксидаза хрена, цитохром С, микропероксидаза и миоглобин), содержащие порфириновые простетические группы, являются представителями семейства ферментов, которые наиболее широко исполь- зовались для создания композитов с МОК для катализа, вероятно, из-за их высокой активности, подходящих размеров и темного цвета для легкого отслеживания.

В 2011 г. была проведена инкапсуляция фермента МП11 в порах Тb-мезоМОК. МП11@ $\mathrm{Tb}$-мезоМОК был использован для катализа окисления 3,5-ди-трет-бутилкатехина в присутствии перекиси водорода $\left(\mathrm{H}_{2} \mathrm{O}_{2}\right)$. После иммобилизации показатели ферментативного катализа были выше по сравнению с его мезопористым кремнеземным аналогом. Далее успешно иммобилизовали миоглобин (Мг) в Ть-мезоМОК [72].

При использовании композита миоглобин@МОК был выявлен размер-селективный биокатализ, а также лучшая каталитическая активность в отношении окисления малых субстратов по сравнению со свободным миоглобином [94].

D. Feng с соавт. разработали серию мезопористых МОК (например, PCN-333 (Al)) для инкапсуляции ферментов (пероксидазы хрена, цитохрома С и МП11). Ферменты, иммобилизованные в PCN-333 (Al), использовали для катализа окисления о-фенилендиамина или 2,2'-азино-бис(3-этилбензтиазолин-6-сульфокислоты) в присутствии $\mathrm{H}_{2} \mathrm{O}_{2}$ [73].

Установлено, что МОК с мезопористыми полостями могут не только вмещать ферменты для повышения их стабильности, но и обеспечивать размерную селективность, которая вряд ли может быть реализована в других системах. Из-за высокой кристалличности МОК пористость может быть высокоорганизованной или однородной, что имеет значение для селективного катализа композитов «фермент-МОК».

Улучшенная селективность катализаторов имеет решающее значение для промышленного их применения. Кроме мезопористых МОК, микропористые MOK ZIF, включая MOK ZIF-8 и MOK ZIF-90, также нашли широкое применение для объединения ферментов при помощи in situ инкапсуляции. При in situ инкапсуляции гостевые молекулы, размер которых больше пор МОК, были внедрены в МОК и выступили в качестве защитной оболочки.

F. Lyu c соавт. впервые попытались внедрить цитохром C в MOK ZIF-8 методом совместного осаждения. Полученный композит показал 10-кратное увеличение пероксидазной активности включенного в МОК фермента по сравнению со свободным цитохромом С [129].

Метод инкапсуляция de novo может широко использоваться для иммобилизации различных видов биомолекул в МОК ZIF-8. Исследователи использовали широкий спектр биомолекул, таких как рибонуклеаза А, сывороточный альбумин человека, пирролохино- 
V.V. Zavyalov, N.V. Zavyalova, V.I. Kholstov et al.

Таблица 2 - Применение композитов «биомолекулы-МОК» [8]

\begin{tabular}{|c|c|c|c|c|}
\hline $\begin{array}{l}\text { № } \\
\Pi / \Pi\end{array}$ & $\begin{array}{c}\text { Композиты } \\
\text { «биомолекулы МОК» }\end{array}$ & Биомолекулы & Функции & Источник \\
\hline 1 & Ть-мезоМОК & МП-11 & Катализ окисления 3,5-ди-трет-бутилкатехина & 72 \\
\hline 2 & PCN-333(Al) & $\begin{array}{l}\text { ПРХ, цитохром C, } \\
\text { МП-11 }\end{array}$ & $\begin{array}{c}\text { Катализ окисления о-фенилендиамина, 2,2'-ази- } \\
\text { но-бис(3-этилбензттиазолин 6-сульфокислота) }\end{array}$ & 73 \\
\hline 3 & PCN-128y & КОФГ & $\begin{array}{c}\text { Детоксикация диизопропил фторфосфата (ДФФ), } \\
\text { зомана }\end{array}$ & 88 \\
\hline 4 & CYCU-4 & Трипсин & Протеолиз БСА & 99 \\
\hline 5 & $\mathrm{UiO}-66-\mathrm{NH} 2$ & $\begin{array}{l}\text { Соевая эпоксид- } \\
\text { гидролаза }\end{array}$ & Гидролиз 1,2-эпоксиоктана & 119 \\
\hline 6 & ZIF-90 & KAT & Катализ и деградация перекиси водорода & 127 \\
\hline 7 & ZIF-8 & Липаза & Катализ и окисление р-нитрофенилбутирата & 154 \\
\hline 8 & ZIF-8 & ГОк & Определение глюкозы & 126 \\
\hline 9 & ZIF-8 & Цитохром C & $\begin{array}{c}\text { Определение пероксида водорода и взрывоопас- } \\
\text { ных органических пероксидов }\end{array}$ & 129 \\
\hline 10 & ZIF-8 & Бычий гемоглобин & Обнаружение перекиси водорода и фенола & 159 \\
\hline 11 & HP-DUT-5 & ГОк, уриназа с ПРХ & Определение глюкозы и мочевой кислоты & 160 \\
\hline 12 & Cu-MOK & Тирозиназа & Обнаружение бисфенола А & 161 \\
\hline 13 & Fe-MIL-88 & ГОк & Обнаружение тромбина & 162 \\
\hline 14 & Cu-MOF & $\begin{array}{c}\text { Нуклеиновые кис- } \\
\text { лоты }\end{array}$ & Определение липополисахаридов & 163 \\
\hline 15 & HKUST-1 & Шпилечные ДНК & Определение ДНК & 168 \\
\hline 16 & Uio-66 & МикроРНК & Определение микроРНК & 170 \\
\hline 17 & био-МОК-1 & Аденинат & Определение $\mathrm{Fe} 3+$ & 172 \\
\hline 18 & $(F e-P) n-M O F$ & ДНК & Определение $\mathrm{Pb} 2+$ & 174 \\
\hline 19 & UiO-66-N3 & ДНК & Доставка лекарств к мишеням & 81 \\
\hline 20 & UiO-Cis & SiPHK & Доставка лекарств к мишеням & 177 \\
\hline 21 & $\mathrm{Zr}-\mathrm{MOK}$ & ДНК & Клеточное поглощение & 182 \\
\hline 22 & ZIF-8 & Гистидин & $\begin{array}{c}\text { Разделение молекул аланина и глутаминовой } \\
\text { кислоты }\end{array}$ & 184 \\
\hline 23 & Cu-MOK & Трипептиды & Энантиоселективное разделения эфедрина & 186 \\
\hline 24 & MIL-101 & Лакказа & Удаление целевых микрозагрязнителей & 187 \\
\hline 25 & CUJAST-1 & Пептиды & Высвобождение пептидов микророботами & 80 \\
\hline 26 & ZIF-8 & $\beta$-галактозидаза & Покрытие пленкой, экзоскелетом & 192 \\
\hline 27 & ZIF-8, ZIF-90 & Антитела & Защита антител & 193 \\
\hline
\end{tabular}


лин-хинон-зависимая глюкозодегидрогеназа, липаза, гемоглобин, лизоцим, пероксидаза хрена, трипсин, уреаза и олигонуклеотид. Результаты показали, что ферменты в ZIF-8 могут сохранять ферментативную активность и в жестких условиях [128].

Впоследствии пероксидаза хрена была внедрена в MOK ZIF-8 с помощью этого же способа. Сформированный композит ПРХ-МОК со средним размером около 30 нм показал повышенную каталитическую активность по сравнению с нативным ферментом [148].

Фермент каталаза впервые был введен в MOK ZIF-90 методом инкапсуляции in situ. Полученные композиты проявляли высокую активность в отношении деградации перекиси водорода даже в присутствии протеазы - протеиназы К $[127,128]$.

Для формирования более сложных комплексов МОК могут быть объединены с другими материалами и биомолекулами. Поэтому различные материалы в этом комплексе могут играть свою собственную роль для выполнения своей цели в применении. Например, Tadepalli S. с соавт. использовали MOK ZIF-8 в качестве защитной оболочки для инкапсуляции золотых наностержней-конъюгатов ПРХ. Этот композит показал повышенную биокаталитическую активность фермента по сравнению с его нативным аналогом за счет фототермического эффекта плазмонных наноструктур [149].

Имеются данные о разработке раздельной системы посредством инкапсулирования наночастиц МОК в капсулах MOK (MOK-Cs). Этот композит способен защитить иммобилизованные ферменты (каталазу, глюкозооксидазу, пероксидазу хрена и протеазу) от денатурации и поддерживать их активность [150]. С другой стороны, и различные ферменты могут быть включены в одну систему для каскадного использования.

В 2015 г. был разработан новый метод иммобилизации ферментов с использованием непрерывной капельной микрофлюидной системы MIL-88A (Fe). Образовавшиеся полые сферы MIL-88A (Fe) могли одновременно инкапсулировать три различных фермента (глицериндегидрогеназу, пероксидазу хрена и ацетилхолинэстеразу). Было установлено, что иммобилизованные ферменты проявляли большую активность и обратимость, чем свободные ферменты [151].

Другой класс ферментов, гидролазы, также широко использовались для создания композитов «фермент-МОК». Для этих целей использовал МОК ПХН-128у для иммобилизации кислой органофостфатангидролазы (КОФГ). КОФГ@ПХН-128у. Указанный композит «фермент-МОК» был применен для детоксикации диизопропилфторфосфата (ДФФ) и зомана чрезвычайно токсичного нервно-паралитического отравляющего вещества. Этот новый гибридный материал продемонстрировал высокую конверсию данных веществ в течение нескольких минут [88].

В МОК канального типа, таких как МОК PCN-128y, ферменты могут входить в МОК без изменения их конформации, благодаря чему они могут хорошо поддерживать свою активность. С другой стороны, каналы в МОК могут также действовать как субстратные каналы для облегчения взаимодействия между ферментами и их субстратом. Для создания МОК канального типа объединения должна быть тщательно обдумана и выбрана его структура, чтобы избежать возможного вымывания биомолекул. Необходимо отметить, что сами органические лиганды в стенке канала МОК могут обеспечивать относительно сильные взаимодействия, что облегчает удержания биомолекул.

Соевая эпоксидгидролаза была иммобилизована на MOK UiO-66-NH2 посредством ковалентного связывания. Этот композит использовали для катализа гидролиза 1,2-эпоксиоктана и его активность была сравнима с активностью свободного фермента [119].

W.-L. Liu c соавт. разработали композит трипсин@CYCU-4, меченного флуоресцеинизотиоцианатом. Этот биореактор показал высокую эффективность расщепления БСА [99].

S. Rafiei с соавт. путем инкапсуляции липазы в каркас микропористого цеолита имидазола MOK ZIF-67 создали новый биокатализатор. Полученный композит липаза@ZIF-67 успешно применяется для катализа переэтерификации соевого масла в биодизельное топливо [152].

MOK UiO-66 был использован $\mathrm{Hu} \mathrm{Y.} \mathrm{с}$ соавт. в качестве матрицы-хозяина для иммобилизации липазы Aspergillus niger посредством гидрофобных взаимодействий. Гидрофобная модификация MOK UiO-66 значительно повысила каталитическую активность липазы для получения биодизельного топлива [153].

Фермент липаза был иммобилизован в MOK ZIF-8 методом синтеза «в одном котле». Полученный композит липаза@МОК далее был использован для катализа окисления р-нитрофенилбутирата (РНФБ) [154]. Для катализа специфических реакций окисления, кроме липазы, в МОК также были иммобилизованы оксидазы.

L. Shi c соавт. получен MOK, подобный пористому углепластику ZIF-8, для инкапсуляции глюкозооксидазы (ГОк). Встроенный в этот МОК фермент ГОк показал большой объем загрузки и быструю активность пере- 
носа электронов [155]. Путем инкапсуляции была создана мультиферментная система из глюкозооксидазы и уриназы, которая затем была включена в иерархически пористые МOK HP-PCN-224 (Fe). В исследовании X. Liu с соавт. HP-PCN-224 (Fe) проявил себя эффективным аналогом фермента, который мог сотрудничать с иммобилизованным ферментом для тандемного катализа [156].

За последние десятилетия ферментативный или белково-опосредованный биокатализ привлек значительное внимание исследователей в различных областях, особенно в пищевой и фармацевтической промышленности. Установлено, что разнообразные МОК успешно сочетаются с ферментами для повышения их активности, стабильности и специфичности.

Однако для расширения типов реакций, которые могут катализироваться биокатализаторами «фермент-МОК», и увеличения их практического применения необходимо проведение дополнительных исследований. Кроме того, эти новые биокатализаторы нуждаются в дополнительной оценке и эксплуатации в расширении диапазона условий проведения реакций, особенно в реальных промышленных или биологических условиях.

Биосенсоры. Рассматриваются как перспективный инструмент для быстрого, избирательного и чувствительного анализа целевых молекул. Для этих целей были разработаны и созданы композиты «биомолекулы-МОК» в качестве инновационной сенсорной платформы для широкого обнаружения экологических и биологически значимых целевых молекул, таких как глюкоза, L-цистеин, $\mathrm{H}_{2} \mathrm{O}_{2}$, дофамин и аскорбиновая кислота [157-159].

B работе F. Lyu с соавт. впервые был сконструирован композит цитохрома С и MOK ZIF-8 с использованием метода in situ инкапсулирования. Полученный композит использовался для флуорометрического определения пероксида водорода и взрывоопасных органических пероксидов, включая метилэтилкетонпероксид (МЭКП) и третичный бутилгидропероксид (ТБГП). Этот гибридный материал быстро и чувствительно реагирует на $\mathrm{H}_{2} \mathrm{O}_{2}$, МЭКП и ТБГП [129].

Был создан композит бычьего гемоглобина (БНb) с MOK (БНb@ZIF-8), который быстро выводил сигналы при обнаружении $\mathrm{H}_{2} \mathrm{O}_{2}$ и фенола. Кроме того, была разработана мультиферментная миметическая система, в состав которой входили ГОк и магнитный ZIF-8 (mZIF-8) [158].

Для определения содержания глюкозы использовали композит ГОк@mZIF-8. Благодаря магнитным свойствам mZIF-8, эта система была легко переработана. Установлено, что переработанные композиты проявляли почти такую же активность после нескольких циклов работы [126].

Датчик для in vivo мониторинга глюкозы путем построения электрохимической системы был разработан на основе глюкозодегидрогеназы (ГДГ)-ZIF. Результаты исследования показали, что эти биосенсоры на основе ZIF могут избирательно определять глюкозу непосредственно в мозге морских свинок в режиме, близком к реальному времени [102].

Помимо биосенсоров на основе ZIF, для построения мультиферментной системы каскадных реакций использовались также МОК с иерархическими порами. Частичные связи между этими иерархическими порами могут способствовать массопереносу субстратов и продуктов при катализе и зондировании.

X. Liu с соавт. разработали легкий и простой способ иммобилизации ферментов с использованием иерархически пористых металлорганических каркасов (НР-МОК). Ими были сконструированы два мультиферментных биосенсора для глюкозы и мочевой кислоты путем иммобилизации ГОк и уриназы с помощью пероксидазы хрена (ПРХ) на HP-DUT-5 соответственно. Эти датчики показали хорошую чувствительность, селективность и пригодность для повторного использования для обнаружения глюкозы и мочевой кислоты [159].

Для электрохимического определения бисфенола А (БФА) был создан композит хитозана с МОК и тирозиназой, который исследован в качестве электрохимического датчика для бисфенола В (БФВ), бисфенола F (БФF), бисфенола Е (БФЕ) и бисфенола Z (БФZ) [160].

Еще один нанокомпозитный материал PtNPs-MOK-GOD бал создан для электрохимического зондирования глюкозы. Этот композит проявлял исключительную селективность по отношению к глюкозе даже в присутствии других сахаров (фруктозы, галактозы и монозы), аскорбиновой кислоты и мочевой кислоты. Датчик показал хорошие результаты для точного определения глюкозы в сыворотке крови больных сахарным диабетом [71].

S. Xie с соавт. сообщили о создании многофункционального биоконъюгата Au-hemin@ MOK-TBA II (тромбин-связывающий аптамер) с ГОк (глюкозооксидаза) для электрохимического зондирования тромбина (ТБ) [161]. W.-J. Shen с соавт. создан другой композит AuNPs-MOK, который использовался для иммобилизации наночастиц и обнаружения липополисахаридов. Сенсор проявлял специфичность по отношению к липополисахариду в присутствии человеческого сывороточного 
альбумина, прокальцитонина и С-реактивного белка [162]. Аналогично, использовали композит Ag-MOK(Zn-TSA) в качестве высокоэффективных матриц иммобилизации миоглобина $(\mathrm{Mb})$ и глюкозооксидазы для электрохимического определения перекиси водорода, нитрита и глюкозы [163]. Впоследствии был синтезирован ряд МОК, содержащих $\mathrm{Fe}^{3+}, \mathrm{Zr}^{4+}$, $\mathrm{La}^{3+}$ и 2-аминотерефталат (Н ATA), которые успешно были применены в качестве матриц иммобилизации ацетилхолинэстеразы (АХЭ) для построения биосенсоров с целью детекции метилпаратиона [164].

Композиты ГОк-MOK (GOx@ZIF-8) использовали в качестве блока трансдукции сигнала через процесс биомиметической минерализации для построения флуоресцентного иммуносенсора для галектина-4. Разработанный композит применялся для мониторинга галектина-4 в реальных раковых образцах. Эта сенсорная система была также способна обнаруживать целевые белки в клеточных лизатах [165].

B работе Gong C. с соавт. проведено инкапсулирование МП-11 в PCN-333 (Al), полученный композит нашел свое применение в качестве биосенсора для перекиси водорода [166].

В последние несколько лет биосенсоры на основе МОК продемонстрировали хорошие результаты в обнаружении ДНК и РНК. Разработанный ДНК-сенсор, основанный на миметическом катализе МОК и аллостерическом переключении шпильки ДНК, осуществляет специфическое распознавание между структурой аптамера и стрептавидином (CA). Датчик ДНК на основе МОК способен обнаруживать ДНК-мишень в линейном диапазоне обнаружения от 10 фМ до 10 нМ [167].

J. Chen с соавт. разработали электрохимический датчик ДНК, построенный на основе комбинации модифицированного биотином зонда захвата с композитом гемин-MOK-PtNPs. Этот новый биосенсор показал чувствительное обнаружение гена FGFR3 (рецептора фактора роста фибробластов 3) от 0,1 фМ до 1 нМ и низкий предел обнаружения 0,033 фМ [168].

Новая стратегия зондирования, основанная на пептидных зондах нуклеиновых кислот (ПНК), меченных флуорофорами и конъюгированных с нано-МОК-носителем (nMOK), представлена в работе Y. Wu с соавт. [169]. Данный композит использовался для мониторинга мультиплексированных микроРНК в живых раковых клетках. В присутствии микроРНК-мишени ПНК гибридизовалась и высвобождалась из $\mathrm{nMOK,} \mathrm{что} \mathrm{приводило} \mathrm{к}$ восстановлению сигнала флуоресценции.

Известно, что ионы тяжелых металлов в сточных водах представляют большую угрозу окружающей среде и здоровью животного мира. Существует ряд композитов «биомолекулы-МОК», которые могут эффективно обнаруживать ионы металлов в сточных водах. Так, в работах $[170,171]$ сообщается о серии аденинатных встроенных MOK (био-МОК-1), полученных путем инкапсуляции различных ионов лантаноидов (например, $\mathrm{Eu}^{3+}$ или $\mathrm{Tb}^{3+}$ ) с помощью постсинтетического метода катионного обмена. Такие био-МОК были использованы для определения содержания $\mathrm{Fe}^{3+}$ в сточных водах. Таким же образом $\mathrm{Eu}^{3+}-\beta$-дикетонат, помещенный в био-МОК-1, проявлялся изменением цвета в присутствии органических аминов (например, метиламин). Этот анионный био-МОК может выступать в качестве базового, поскольку катионные гостевые молекулы могут принимать участие в поверхностном обмене с другими катионными видами. Впоследствии исследователи разработали композит путем получения одноцепочечной ДНК, меченной КФЦ (карбоксифлуоресцеин), с Еu ${ }^{3+}$ @био-MOК-1. Этот гибридный материал может быть использован для обнаружения $\mathrm{Cu}^{2+}$ с пределом обнаружения 0,14 мкМ [172]. Далее ученые разработали электрохимический биосенсор на основе наночастиц $\mathrm{Au}$ на бумажном рабочем электроде для обнаружения $\mathrm{Pb}^{2+}$ с использованием ДНК-модифицированных железопорфириновых гибридов MOK ((Fe-P) nMOK-Au-GR) в качестве сигнальных зондов. Биосенсор был селективен для $\mathrm{Pb}^{2+}$ в присутствии многих других конкурирующих ионов металлов [173]. В том же направлении был создан композит, объединивший МОК с одноцепочечной зондовой ДНК (ss-ДНК, обозначаемой как Р-ДНК), меченной флуорофором КФЦ. Этот биосенсор высокоселективен и чувствителен к $\mathrm{Hg}^{2+}$ с пределом обнаружения 3,2 нМ [174].

В последние годы проведенные исследования были посвящены быстрому и точному обнаружению биологических молекул, нуклеиновых кислот и ионов металлов и т. д. с помощью биосенсоров.

Биосенсоры показали большие возможности в этой области, благодаря высокой чувствительности и селективности. Сочетание биомолекул с МОК не только улучшает стабильность, многократность использования и способность биораспознавания формируемых биосенсоров, но и повышает их селективность за счет специфических взаимодействий биомолекул-аналитов. Несмотря на достижения композитов на основе биомолекул и МОК в области биоаналитической химии, для оптимизации этих гибридных материалов и для обнаружения одиночных молекул и тестирования, применяемого при оказании первой медпомощи, необходимо проведение дополнительных исследований. 
Доставка лекарств и молекулярная визуализация. Со времени выхода в свет в 2006 г. работы P. Horcajada с соавт. [175] было доказано, что МОК являются перспективной платформой для доставки лекарств из-за их высокой степени загруженности лекарством, возможности биологического разложения и функциональности. После уменьшения размера до наноразмерного у включаемых частиц в МОК стало возможным использовать нано-МОК (nМОK) в качестве эффективных наноносителей для доставки контрастных веществ для визуализации, химиотерапии и других видов медицины. Основными исследованными молекулами, включенными в MOK, были бимолекулярные препараты - нуклеиновые кислоты и белки.

Впервые композит «нуклеиновая кислота-МОК» на основе ДНК, функционализированной дибензилциклооктином (ДБЦО), и UiO-66-N3.был синтезирован W. Morris c соавт. в 2014 г. [81]. Полученные результаты показали более высокую эффективность включения наночастиц (14 и 19 нм), композитами «ДНК-МОК», чем у нефункционализированных наночастиц МОК.

Тогда же С. Не с соавт. сообщили о совместной доставке цисплатина и малых интерферирующих рибонуклеиновых кислот (siPHК) с использованием частиц UiO-MOK в качестве наноносителей. Этот композит может не только стабилизировать UiO-MOK, но и защитить siРНК от деградации нуклеазами и тем самым облегчить поглощение siPHК клетками [176].

Помимо нуклеиновых кислот, другие биологически активные молекулы также могут быть доставлены в клетки, образуя комплекс с МОК. Нанокомпозит по типу «ядро-оболочка» был синтезирован с использованием бычьего сывороточного альбумина (БСА) в качестве ядра и рН-чувствительного МОК в качестве оболочки. При этом в ядро БСА до образования оболочки в МОК был инкапсулирован доксорубицин. Композит показал гораздо более высокую эффективность против линии клеток рака молочной железы MCF-7, чем свободный доксорубицин [134].

Новый био-MOK (bioMIL-1) синтезирован S.R. Miller c соавт. из нетоксичного железа и биоактивного линкера никотиновой кислоты. Никотиновая кислота может высвобождаться в результате деградации bioMIL-1 в моделируемых физиологических условиях, что обеспечивает доставку биологически активной молекулы в клетки [177].

S. Wang с соавт. в 2017 г. функционализовал наночастицы МОК олигонуклеотидами на основе стратегии координационной химии. Эта работа дала нам новую группу конъюгатов «нуклеиновые кислоты-МОК», для манипули- рования внутриклеточными процессами и их измерения [82].

Особый интерес представляет информация о нанореакторе «тирозиназа-МОК», который может активировать пролекарство парацетамола в раковых клетках. Регулируя концентрацию активных форм кислорода и глутатиона, X. Lian с соавт. доказали возможность получить продукт парацетамола, который будет убивать лекарственно устойчивые раковые клетки [70].

S. Wuttke с соавт. синтезировали МОК-липидные наночастицы. Молекулы красителя ими были эффективно иммобилизованы в порах МОК, в то время как липидный бислой препятствовал их высвобождению. Эффективное поглощение МОК-липидных наночастиц раковыми клетками показал перспективность этих композитов для доставки лекарственных средств и визуализации клеток [178].

В литературе имеются данные об изучении многофункциональных зондов на основе МOK для двух модальной оптической визуализации. Y. Liu c соавт. на основе $\mathrm{Zr}$ получили наночастицы МОК, конъюгированные с ДНК, которые являются аптамерами для мишень-индуцированного биоимиджинга и фотодинамической терапии. Результаты проведенных исследований показали, что мишень-индуцированная визуализация достигается за счет структурного изменения аптамера при связывании с молекулами-мишенями. Кроме того, композит «ДНК-МОК» может значительно усиливать эффект фотодинамической терапии [179].

Нанокомпозит «ядро-оболочка», синтезированный путем объединения $\mathrm{pH}$-чувствительной оболочки МОК с пептидно-функционализированной наночастицей золота, можно использовать в качестве переключателя двойного распознавания в кислой среде. Такое использование позволяет по-новому визуализовать лизосомальный катепсин.

Композит «ДНК-МОК», полученный путем внутренней координации цитозинфосфат-гуанозиновых олигонуклеотидов на биосовместимых наночастицах циркония, проявляет высокое клеточное поглощение, специфичность к органеллам и пространственно-временной контроль толл-подобных рецепторов, запускающих иммунные реакции $[180,181]$.

С помощью биосовместимого инкапсулирования белков в МОК создан композит, который обладает высокой эффективностью (до 94\%) и высокой загрузочной способностью. Установлено, что образовавшиеся наночастицы могут защитить гостевые белки от переваривания протеазами. Кроме того, они могут улучшить их поглощение опухолевыми клетками и автономное высвобождение молекул-гостей [182]. 
Разделение молекул. МОК идеально подходят для применения в процессе разделения молекул на основе определенных открытых каналов, полостей молекулярного размера, площади внутренней поверхности и простоты модификации [183].

J. Zhaо с соавт. показано, что композиты «биомолекулы-МОК» обладают большим потенциалом для энантиоселективного разделения биомолекул и удаления тяжелых металлов, пестицидов и красителей. Созданный МОК имел микропористую структуру с хиральной средой. Композит синтезировали путем простого замещения лиганда 2-метил имидазолата D-гистидином. При экспериментальной проверке этот хиральный композит МОК продемонстрировал исключительную селективную способность к разделению рацемического аланина и глутаминовой кислоты [184].

J. Navarro-Sánchez с соавт. и Ren Z. с соавт. практически одновременно сообщили о создании биокаталитической мембраны с иммобилизованной лакказой для удаления микрозагрязнителей. Для этого полиэтиленимин (ПЭИ), МОК, лакказу и полидофамин (ПДА) последовательно модифицировали на разделительных и опорных слоях ультрафильтрационной мембраны из полиакрилонитрила (ПАН). Созданные биокаталитические мембраны LacPAN-MIL-101-L показали высокую проницаемость с эффективным удалением целевых микрозагрязнителей $[185,186]$.

В работе Mon M. C соавт. приведены данные о создании прочного и водостойкого МОК с остатками метионина. Такой МОК может избирательно захватывать из воды токсичные примеси, такие как $\mathrm{CH}_{3} \mathrm{Hg}^{+}$и $\mathrm{Hg}^{2+}$, и демонстрирует наибольшую способность поглощения $\mathrm{Hg}^{2+}$ среди всех зарегистрированных MOK [187].

В дополнение к вышеупомянутым сферам использования известны и другие интересные предложения по применению композитов «биомолекулы-МОК». Например, при включении пептида в МОК был создан биохимический активный сенсор. Этот композит «пептид-МОК» может определять токсичные тяжелые металлы в растворе, передвигаясь («доплывая») до них самостоятельно [80]. В дальнейшем был разработан новый дифенилаланиновый (ДФА) пептид на основе МОК HKUST-1. Этот микроробот может высвобождать пептиды ДФА без разрушения HKUST-1 через водный обмен в порах [78].

J.S. Kahn с соавт. получили модифицированный композит "ДНК-МОК», реагирующий на раздражители. Ими синтезированы реагирующие на $\mathrm{pH}$ и $\mathrm{K}^{+}$ДНК-функционали- зированные МОК, которые являются перспективными для совершенствования сенсоров, новых катализаторов и носителей для доставки лекарственных средств [188].

Y. Guo с соавт. вводили однонитевые молекулы ДНК в мембраны ZIF-8 в ходе твердофазного синтеза. Полученная таким образом ДНК-конъюгированная мембрана ZIF-8 обладала высокой протонной проводимостью и высокой селективной проницаемостью. Результаты могут быть полезны в дальнейших исследованиях возможностей функционализированных мембран на основе МОК для использования в топливных элементах [189].

МОК могут быть также использованы для создания экзоскелетов для микроорганизмов. Например, гомогенное покрытие ZIF-8 может защитить живые клетки от противогрибковых агентов и крупных цитотоксических белков [190]. Защитная оболочка МОК создана для дрожжевых клеток. Сначала их покрывали $\beta$-галактозидазой, а далее на ферментном покрытии образовалась пленка МОК. Она позволяла клеткам выживать в моделируемых экстремальных олиготрофных средах более 7 сут [191].

Разработанная в 2019 г. Y. Feng с соавт. платформа на основе систем ZIF-8 и ZIF-90 оказалась эффективной для защиты антител и значительного повышения их термической, химической и механической устойчивости. Показано, что МОК может полностью инкапсулировать и высвобождать человеческие и козьи антитела $\mathrm{IgG}$ или коммерческий препарат адалимумаб в очень короткие сроки с высокой эффективностью. Кроме того, защищенные антитела могут сохранять структурную целостность и биоактивность в жестких условиях, включая высокую температуру, механическую силу, органический растворитель и циклы замораживания. Защищенные антитела могут также выжить при длительном хранении в условиях изменения температуры окружающей среды [192].

Проведение таких исследований в дальнейшем будет способствовать применению МОК в биомедицинских областях и обеспечит стабильность хранения биофармацевтических препаратов.

Таким образом, в последние нескольких лет большое внимание исследователей привлекало включение (внедрение) биомолекул в МОК для применения в различных областях, включая материаловедение, биохимию, неорганическую химию и медицину. Действительно, МОК демонстрируют большие преимущества в качестве платформ для иммобилизации биомолекул. Однако развитие этой области все еще находится в зачаточном состоянии. Изложенные современные направления подготовки биомолекул к объединению с МОК имеют 
большое значение для применения созданных к настоящему времени композитов «биомолекул-МОК» в биокатализе, биосенсорах, сепарации и других областях.

Хотя в этой области исследований были достигнуты значительные успехи в создании и применении различных композитов «биомолекул-МОК», однако проблема включения биомолекул все еще остается. Что касается стратегий иммобилизации, несмотря на то, что было разработано несколько методов, все они имеют свои достоинства и недостатки. Например, адсорбционные методы обычно могут поддерживать высокую активность биомолекул, но этот метод значительно ограничен размерами биомолекул и размером пор МОК. Кроме того, «гостевые молекулы» имеют только слабые взаимодействия с МОК и склонны к выходу из матрицы. Ковалентная связь часто может преодолеть этот недостаток, но этот метод является сложным и дорогостоящим, а иногда влияет на активность биомолекул. Инкапсуляция in situ не предъявляет особых требований к размеру «гостевых молекул». Но эта стратегия может осуществляться только в мягких условиях в водных растворах, что исключает многие МОК, которые не могут быть синтезированы в этих условиях. Поэтому изучение этих подходов к объединению биомолекул в МОК или исследование новых стратегий могут еще больше продвинуть вперед эту область и расширить сферу применения создаваемых композитов. Кроме того, редко сообщается о работе композитов «биомолекул-МОК» в промышленных или биологических условиях. Поэтому существует необходимость изучения поведения таких композитов в разных средах. Также требуются углубленные исследования более практических и конкретных функций композитов «биомолекул-МОК». Кроме того, для практического применения существует необходимость крупномасштабного процесса подготовки для получения недорогих композитов.

Таким образом композиты «биомолекулы-МОК» являются эффективной платформой в различных областях, таких как биокатализ, биосенсор, разделение молекул, доставка лекарств, микрореакторы и микроботы. В будущем, очевидно, будут также представлять интерес другие направления объединения биомолекул с МОК и расширение спектра МОК или МОК-гибридных материалов, которые необходимы для работы с крупными биомолекулами промышленного значения. В целом, хотя все новые композиты созданы только благодаря теоретическим исследованиям, однако можно предположить, что разработка композитов «биомолекулы-МОК» будет иметь огромный потенциал для дальнейшего развития.

4. Практическое применение теоретических знаний о металлоорганических каркасах с включенными биомолекулами

Создание металлоорганических комплексов с заданными свойствами из модулей для современных средств защиты от токсичных химикатов и микроорганизмов является одним из наиболее перспективных направлений практического применения теоретических знаний о металлоорганических каркасах с включенными биологическими молекулами.

По нашему мнению, создание материалов и тканей со специальными свойствами на основе МОК представляет собой область исследований, которая позволяет осуществить переход от теоретических воззрений к прикладным работам по созданию средств индивидуальной и коллективной защиты нового поколения при конструировании, которых не используются уже готовые ткани и материалы, а создаются условия, способствующие самосборки материала с заданными свойствами. Для этой цели, прежде всего необходимо выбрать из известных, теоретически разработанных подходов наиболее приемлемые для создания МОК и композитов «биомолекулы-МОК». Далее, создать соответствующие металлоорганические комплексы, подобрать биологические и химические молекулы, обеспечивающие проявление заданных свойств, интегрировать эти молекулы в МОК и на основе всего этого создать композиты «биомолекулы-МОК», способные катализировать деградацию (гидролиз) токсичных химикатов и уничтожать болезнетворные микроорганизмы.

При создании МОК и композитов «биомолекулы-МОК» наиболее приемлемыми для создания материалов и тканей со специальными защитными свойствами представляются in situ инкапсуляция и био-МОК способ получения металлорганических комплексов. Как уже было отмечено ранее, in situ инкапсуляция - это довольно распространенный подход для объединения биомолекул с МОК. Использование этого способа инкапсуляции приводит к созданию МОК вокруг биомолекул с одновременным эффективным включением этих биомолекул в поры при отсутствии их вымывания.

Преимуществами такой in situ инкапсуляции являются: отсутствие каких-либо ограничений по размеру биомолекул; быстрота и небольшая стоимость способа; возможность инкапсулировать аминокислоты, белки и ферменты с высокой эффективностью включения их в процессе формирования МОК. Созданные таким образом МОК могут выступать также в качестве защитных покрытий для биомакромо- 
лекул. Из литературы известно, что инкапсулированный белок в наночастицы МОК не теряет своей активности, а полученный гибридный материал приобретает высокую чувствительность, селективность, а также стабильность при длительном хранении.

Недостаток in situ инкапсуляции заключается в обязательности реализации этой технологии только в мягких условиях - в водных растворах, поскольку большинство биомолекул не могут выжить в агрессивных синтетических условиях, таких как высокая температура и органические растворители.

Многокомпонентная система, используемая в in situ инкапсуляции, открыла новые перспективы для подготовки и применения получаемых гибридных материалов в разных областях, таких как промышленный биокатализ, фармацевтика и биомедицинские устройства.

При использовании био-МОК способа получения металлорганических комплексов, биомолекулы-аминокислоты, пептиды, нуклеотиды и сахариды, обладающие химически активными группами, могут хорошо координироваться с различными металлами и выступать в качестве органических линкеров для синтеза МОК. Использование этих биомолекул в качестве лигандов для координации с металлами приводит к формированию совершенно новых типов МОК. Био-МОК склонны к лучшей биосовместимости и обеспечивают особую функциональность. Недостатком данного подхода является асимметрия и высокая гибкость биомолекул. Поэтому при био-МОК способе используют высокосимметричные биомолекулы.

Согласно предложенному переходу от теоретических к прикладным работам, первоочередным является выбор специальных свойств, которыми должны обладать разрабатываемые материалы и ткани на основе MOK, которыми не обладали предыдущие поколения материалов и тканей для средств индивидуальной защиты.

В соответствии с ранее проведенными теоретическими и практическими исследованиями $[1,3]$, нами были выбраны свойства бактерицидность и самоочищение (самодегазация). Данные свойства материалы и ткани могут приобретать за счет их функциализации, при использовании наноразмерных металлосодержащих частиц - кобальта, титана, цинка, серебра и др., и наноразмерных ферментных комплексов (органофосфатгидролазы, карбоксипептидазы А, лактоназы), которые предполагаются для каскадного использования.

Для построения МОК требуются органические лиганды. Такими лигандами могут быть аминогруппы или пептиды. В качестве органических линкеров для построения МОК можно использовать аминокислоты, пептиды и высокоэнергетические наночастицы металлов: тантала, титана, цинка, размером от 1 нм до 3 нм.

Металлоорганические композиты с введенными в них одновременно антимикробным компонентом и наноразмерными ферментными комплексами предлагаем наносить на тканевую унифицированную платформу.

Порядок и последовательность нанесения указанных металлоорганических композитов «биомолекулы-МОК» на тканевую унифицированную платформу могут быть основой для разработки технологии получения нового поколения материалов и тканей модульного типа со специальными свойствами.

Полученные таким способом композиты «биомолекулы-МОК» могут быть использованы в качестве новых платформ для гетерогенного биокатализа, так как они имеют ряд преимуществ: высокую стабильность и многократное использование, и лучшую каталитическую селективность.

Стратегия создания металлоорганических комплексов с заданными свойствами из модулей для средств, обеспечивающих защиту человека от различных поражающих факторов химической, биологической и физической природы. После выбора подходов создания металлоорганических комплексов и композитов «биомолекулы-МОК», a также определения биологических и химических молекул, обеспечивающих проявление заданных свойств, способных интегрироваться в МОК, нами была разработана стратегия создания металлоорганических комплексов с заданными свойствами из модулей для современных средств защиты от токсичных химикатов и биологических поражающих агентов и определены направления проведения экспериментальных исследований по проверке заданных свойств.

Разработка стратегии модульности МОК при создании современных средств защиты, базируется на анализе литературных данных по направлениям получения композитов «биомолекулы-МОК», их свойствам и возможным областям применения.

Предлагаемая нами стратегия создания защитных материалов состоит в использовании единой тканевой унифицированной платформы с нанесением на ее поверхность специальных модулей, которые будут обеспечивать защиту человека от различных факторов химической, биологической и физической природы.

На наш взгляд, модульность должна состоять в комплектовании пакета материалов, используемых в защитной одежде, общими элементами защиты от различных факторов 


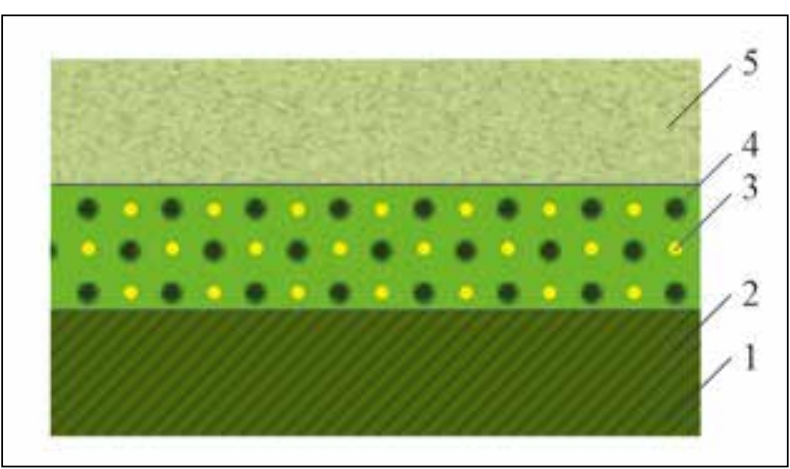

Рисунок 4 - Схема порядка формирования (нанесения компонентов) разрабатываемого универсального «МОК-универсальный».

1 - модуль «Абсорбционный» - подложка, ткань параарамидная (волокно «Русар»);

2 - модуль «Адгезионный», карбоксилаты металлов (агент № 1); 3 - модуль

"Антибактериальный», наночастицы

металла тантала (агент № 2); 4 - модуль

«Химический», капсулы алкоголятов металлов

(агент № 3); 5 - модуль «Биохимический» или

«Самодегазирующийся», капсулы наноразмерных ферментных комплексов (агент № 4)

воздействия на человека. Сам защитный материал классифицируется как модуль «Ткань» или модуль «Броня».

Модуль «Ткань» представляет собой унифицированную платформу, на которую наносятся другие специальные модули.

Согласно нашему представлению на модуле «Ткань» размещается модуль «Адгезионный». Основное назначение модуля «Адгезионный» состоит в обеспечении адгезии остальных модулей на тканевой унифицированной платформе.

По предлагаемой спецификации модули классифицируются по своему назначению следующим образом:

- модуль, защищающий от открытого пламени и светового излучения ядерного взрыва «Противоогневой»;

- модуль, защищающий от бактериальных агентов - «Дезинфицирующий»;

- модуль, защищающий от сильнодействующих ядовитых веществ - «Дегазационный».

По механизму действия «Дегазационный» модуль может быть: «Биохимический»; «Химический»; «Адсорбционный»; «Абсорбционный».

Сама классификация по какому-либо признаку является дополняющей и определяющей точное назначение и защитные свойства и особенности того или иного модуля.

По продолжительности действия различаем модули «Кратковременного действия» и «Длительного действия».
По защитным свойствам модули подразделяются по классам токсичных химикатов.

Металлоорганический комплекс (МОК) может быть отнесен к «Металлоорганическому» модулю, относящемуся к модулю «Биохимический», а применяемый совместно с модулем «Дезинфицирующий» стать основой разработки технологии получения материалов и тканей со специальными свойствами модульного типа, обеспечивающими одновременную защиту от токсичных химикатов и болезнетворных патогенных микроорганизмов.

Для создания материалов и тканей со специальными свойствами модульного типа, обеспечивающими защиту от токсичных химикатов и болезнетворных микроорганизмов, на основе МОК, нами были выделены несколько направлений конструирования по структуре и проведению проверки вышеуказанных свойств.

Первое направление - разработка универсальной структуры МОК с наиболее насыщенной по количеству модулей и вводимых в них компонентов, получившей название «МОК-универсальный» (МОК-1).

В структуру «МОК-универсальный» (MOK-1) предложено ввести следующие модули, состоящие из слоев:

1. Модуль «Ткань» - слой ткани, которая является подложкой;

2. Модуль «Адгезионный» он же «Абсорбционный» - слой карбоксилатов металлов (агент № 1), в котором в качестве неполярной части молекулы используется природная карбоновая кислота с высоким гидрофобным взаимодействием, а в качестве металлов предлагается использовать: алюминий, железо, стронций, барий, медь, марганец, никель, кобальт и цинк. Выбор конкретного карбоксилата металла обусловлен его адгезионными и абсорбционными свойствами;

3. Модуль «Антибактериальный» - слой наночастиц металлов: тантала, титана, цинка, кобальта и железа (агент № 2);

4. Модуль «Химический» - слой капсул алкоголятов металлов, представляющих из себя раствор этилата калия и изопропилата калия в этиловом и изопропиловом спирте соответственно, который заключен в капсулы из поликапролактона или высокомолекулярного полиэтиленгликоля размером от 100 нм до 400 нм (агент № 3);

5. Модуль «Биохимический» или «Самодегазирующийся» (самоочищающийся) - слой капсул наноразмерных ферментных комплексов (агент № 4).

Схема порядка формирования (нанесения компонентов) предлагаемого металлоорганического комплекса «МОК-универсальный» или МОК-1 представлена на рисунке 4. 
В модуле «Абсорбционный» - подложка, в качестве подложки, целесообразно использование кроме параарамидной ткани (волокно «Русар») другие виды тканей, такие как: вискоза, шелк, метаарамид (волокно «Номекс»).

Назначение модуля «Абсорбционный» подложка заключается в абсорбции на ее поверхности всех слоев других агентов, которые обеспечивают универсальную защиту от воздействия токсичных химикатов и болезнетворных микроорганизмов.

На подложку предлагаем наносить (пропитывать) «Адгезионный» модуль, состоящий из карбоксилатов металлов, которые в модуле могут быть разными. Карбоксилаты металлов являются универсальными абсорбентами для паров летучих органических веществ, которые наряду с этим повышают адгезионное крепление на поверхности подложки других агентов. Как до нанесения карбоксилатов металлов, так и после нанесения агента № 1 предусматривается проведение микроскопии подложки. После обработки карбоксилатом металлов подложка просушивается, и на ее поверхность наносятся другие агенты, составные части других модулей, обеспечивающих антимикробные и самодегазирующиеся свойства «МОК-универсальный».

Третий модуль «Антибактериальный» наносится на подложку после карбоксилатов металлов, представляет собой спиртозоли или гидрозоли металлов (тантала, титана, цинка) и обозначается как агент № 2. Данный модуль обеспечивает бактерицидные свойства «МОК-универсальный». После просушки подложки, с нанесенными агентами, также следует микроскопия подложки.

Далее наносится четвертый модуль «Химический», состоящий из капсул алкоголятов металлов, обозначенный как агент № 3, следует последующая просушка и очередная микроскопия подложки.

Жидкие дисперсные системы, содержащие капсулы алкоголятов металлов, приготавливаются заранее.

Капсулирование алкоголята металлов осуществляется путем получения наноразмерных от 100 нм до 500 нм полимерных капсул, состоящих из поликапролактама или ПЭГ-35000 в жидких средах.

Следующим этапом создания «МОК-универсальный» является нанесение пятого модуля «Биохимический» или «Самодегазирующийся», состоящего из микрокапсул наноразмерных ферментных комплексов, обозначенный как агента № 4.

Микрокапсулы ферментов гексагистидинсодержащей органофосфатгидролазы, карбоксипептидазы А и лактоназы также приготав-

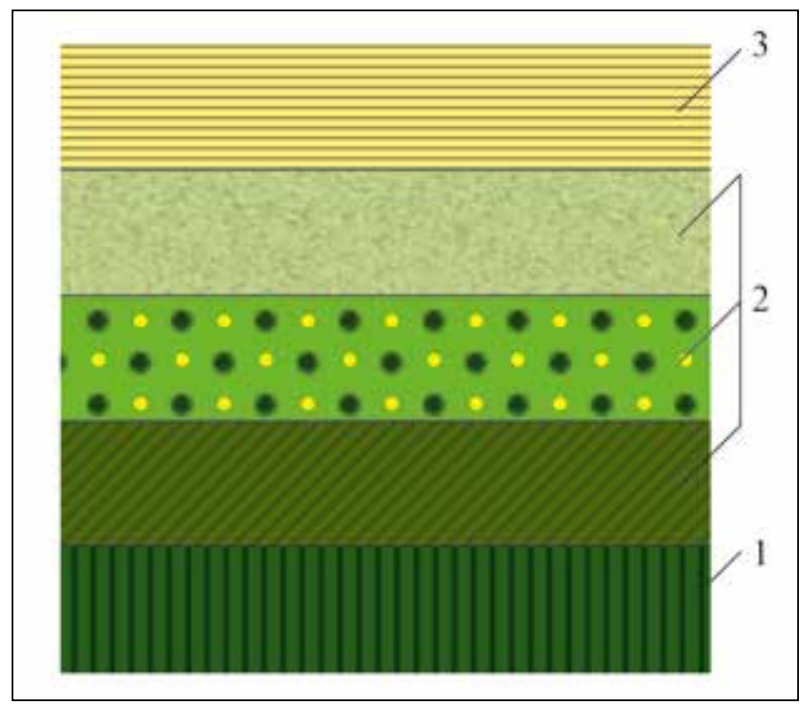

Рисунок 5 - Схема расположения слоев в композитных волокнистых материалах, содержащихся в составе «МОК-универсальный», для испытаний на наличие бактерицидных и «самоочищающихся» (самодегазирующихся) свойств. 1, 3 - слои композитных волокнистых материалов; 2 - «МОК-универсальные»

ливаются заранее. При этом соблюдаются все условия, необходимые для благоприятной каталитической деятельности агента № 4 .

Капсулированные, таким образом, наноразмерные ферментные комплексы оказываются защищенными от агрессивных химических токсикантов. Срок работы капсулированного фермента значительно продлевается до трех лет. После обработки четвертым агентом следует очередная процедура микроскопирования подложки.

Второе направление - конструирование материалов и тканей модульного типа с последующей экспериментальной проверкой свойств структуры «МОК-универсальный» на бактерицидность с помощью тестовых культур микроорганизмов и проверкой свойств «самоочищения» (самодегазации) с использованием ФОС. Для этого «МОК-универсальный» помещается между слоями композитных волокнистых материалов, как показано на рисунке 5 и проводятся указанные выше исследования.

Третье направление - определение важности и значения отдельных модулей и их компонентов (слоев), введенных в структуру «МОК-универсальный». Для проверки работы отдельных модулей и определения их важности в структуре «МОК-универсальный» было предложено создать дополнительно три структуры МОК, получившие название: MOK-2; MOК-3; МОК-4. Схемы порядка соединения модулей и нанесения слоев в предложенных МOК-2, МОК-3, МОК-4 представлены на рисунках 6-8. 


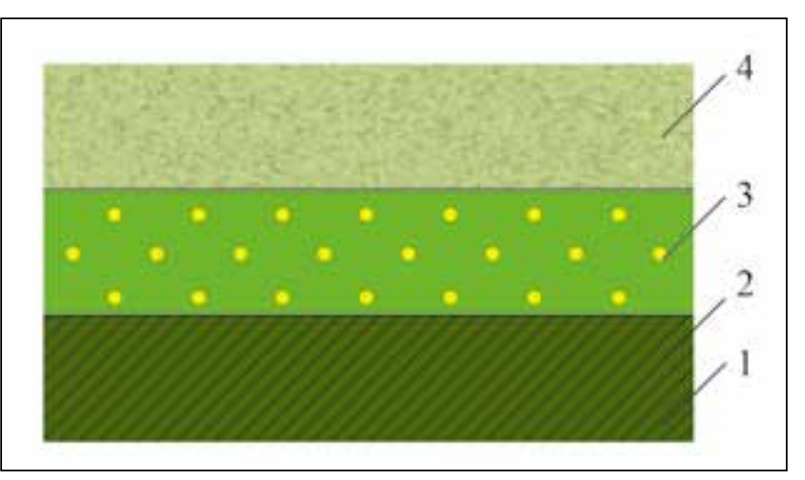

Рисунок 6 - Схема порядка формирования (нанесения компонентов) МОК-2.

1 - модуль «Абсорбционный» подложки, ткань параарамидная (волокно «Русар»); 2 - модуль "Адгезионный", карбоксилаты металлов

(агент № 1); 3 - модуль «Антибактериальный», наночастицы металла тантала (агент № 2); 4 - модуль «Биохимический» или

«Самодегазирующийся» - капсулы наноразмерных ферментных комплексов (агент № 4)

Путем исключения одного из модулей из состава МОК-2, МОК-3 и МОК-4 и сопоставления результатов, полученных при использовании этих трех структур МОК с результатами при использовании структуры «МОК-универсальный», определяем важность и значения отдельных модулей (рисунок 6).

МOK-2 не содержит в своем составе модуль «Химический», капсулы алкоголятов металлов (агент № 3). Исключение из состава модуля «Химический» позволит определить важность и значение этого модуля в составе «МОК-универсальный» при сравнении (сопоставлении) результатов экспериментальных исследований, полученных при изучении свойств МОК-1 и МОК-2.

На рисунке 7 представлена схема порядка формирования (нанесения компонентов) состава МОК-3. В состав данного МОК включены модули: «Адсорбционный», «Адгезионный», «Антибактериальный» и «Химический».

В состав МОК-3 не включен модуль «Биохимический» или «Самодегазирующийся» капсулы наноразмерных ферментных комплексов (агент № 4). Следовательно, при сравнении результатов, полученных при изучении свойств МОК-1 и МОК-3 определяем важность и значение модуля «Биохимический» или «Самодегазирующийся» в предании специфических свойств структуре «МОК-универсальный». На рисунке 8 представлена схема порядка формирования (нанесения компонентов) МОК-4.

Из состава МОК-4 исключен модуль «Антибактериальный» - наночастицы металла тантала (агент № 2). Следовательно, при срав-

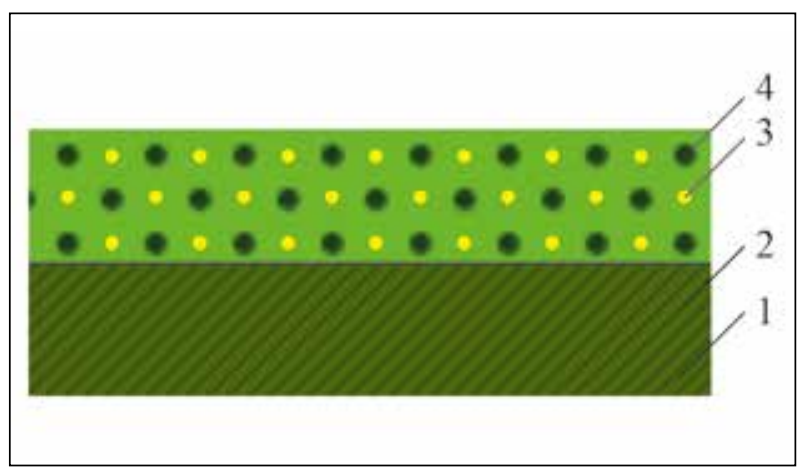

Рисунок 7 - Схема порядка формирования (нанесения компонентов) МОК-3.

1 - модуль «Абсорбчионный» подложки, ткань параарамидная (волокно «Русар»); 2 - модуль «Адгезионный», карбоксилаты металлов (агент № 1);

3 - модуль «Антибактериальный», наночастищы металла тантала (агент № 2);

4 - модуль «Химический», капсулы алкоголятов металлов (агент № 3)

нении результатов, полученных при изучении свойств МОК-1 и МОК-4 определяем важность и значение модуля «Антибактериальный» в предании специфических свойств структуре «МОК-универсальный».

В дальнейшем для экспериментальной проверки свойств, предлагаемых структур МОК-2, МОК-3 и МОК-4 на бактерицидность с тестовыми культурами микроорганизмов и на «самоочищение» (самодегазацию) с токсичными химикатами (ФОС) эти структуры помещаются между слоями композитных волокнистых материалов и проводятся исследования по стандартным методикам.

\section{Заключение}

Проведенный и представленный в обзоре анализ данных литературы по созданию МОК и использованию композитов «биомолекулы-МОК» показал, что все новые подходы по их разработке основываются в основном на теоретических исследованиях. Большая часть из них существует в виде теоретических схематических разработок и далека для практического применения. Однако можно предположить, что создание и использование таких композитов имеет, и будет иметь в будущем важное практическое значение, в различных областях включая материаловедение, биохимию, биокатализ, неорганическую химию и медицину.

Для осуществления перехода от теоретических исследований к практическому применению и использованию композитов «биомолекулы-МОК», например, в области создания новых материалов и тканей с заданными специфическими свойствами, нами 




Рисунок 8 - Схема порядка формирования (нанесения компонентов) МОК-4.

1 - модуль «Абсорбционный» подложки, ткань параарамидная (волокно «Русар»); 2 - модуль «Адгезионный», карбоксилаты металлов (агент № 1); 3 - модуль «Химический», капсулы алкоголятов металлов (агент № 3); 4 - модуль "Биохимический» или "Самодегазирующийся», капсулы

была разработана стратегия создания металлоорганических комплексов с заданными свойствами из модулей для современных средств защиты от токсичных химикатов и патогенных микроорганизмов, обоснованы направления конструирования металлорганических каркасов и композитов «биомолекулы-МОК», определены методы введения биомолекул в МОК, выбраны направления проведения проверки заданных свойств композитов.
Предлагаемая нами стратегия создания защитных материалов состоит в использовании единой тканевой унифицированной платформы с нанесением на ее поверхность специальных модулей, которые будут обеспечивать защиту человека от различных факторов химической, биологической и физической природы.

Разработанный порядок и последовательность введения биологических и химических молекул в металлорганические комплексы, подходы создания композитов «биомолекулы-МОК», порядок и механизм нанесения композитов на защитные ткани, а также определение последовательности введения модулей и порядок нанесения агентов на подложку являются основой для разработки технологии получения нового поколения материалов и тканей со специальными свойствами модульного типа.

Проведенные исследования являются первым этапом экспериментального создания материалов и тканей со специальными заданными свойствами, на основе металлоорганических каркасов и композитов «биомолекулы-МОК».

Следующим этапом практического создания современных СИЗ на основе модульных МОК-материалов со специальными заданными свойствами будет экспериментальное определение важности и значения отдельных модулей и их компонентов (слоев), введенных в структуру МОК по разработанным схемам порядка формирования (нанесения компонентов) предлагаемых металлоорганического комплексов.

\section{Работа выполнена при финансовой поддержке РФФИ (грант № 18-29-17069).}

\section{Информация о конфликте интересов}

Авторы заявляют, что исследования проводились при отсутствии любых коммерческих или финансовых отношений, которые могли бы быть истолкованы как потенциальный конфликт интересов.

\section{Сведения о рецензировании}

Статья прошла открытое рецензирование двумя рецензентами, специалистами в данной области. Рецензии находятся в редакции журнала и в РИНЦе.

\section{Список источников/References}

1. Фосфорорганические нейротоксины: монография / под редакцией С.Д. Варфоломеева и Е.Н. Ефременко, РИОР, Москва, 2020 - 380 с. ISBN: 978-5-369-02026-5. https://doi.org/10.29039/02026-5.

Organophosphorus

Neurotoxins: monograph / Eds. Professor S.D. Varfolomeev \& Professor E.N. Efremenko. Moscow: RIOR, 2020. 380 p. ISBN: 978-5-369-02026-5. https://doi. org/10.29039/02026-5 (in Russian).

2. Khalil E. A technical overview on protective clothing against chemical hazards // AASCIT J. Chemistry.
2015. V. 2. № 3. P. 67-76. https://doi.org/10.6084/ M9.FIGSHARE.1435935

3. Завьялов В.В., Кужелко С.В., Завьялова Н.В. et al. Современные направления создания новых защитных материалов и тканей для средств индивидуальной и коллективной защиты от токсичных химикатов и клеток патогенов // Вестник войск РХБ защиты. 2019. T. 3. №3. C. 117-148. https://doi.org/10.358.25/25875728-2019-3-3-217-254

Zavialov V.V., Kujelko S.V., Zavialova N.V. et al. Modern directions of creating new protective materials and 
tissues for means of individual and collective protection against toxic chemicals and pathogenic microorganisms // Journal of NBC Protection Corps. 2019. V. 3. № 3. P. 217254. https://doi.org/10.358.25/2587-5728-2019-3-3-217-254

4. Soldier systems technology roadmap / Capstone report and action plan / Supporting the future soldier supporting Canadian industry. Government of Canada. URL: https://www.defenceandsecurity.ca/UserFiles/ Uploads/publication/reports/files/document-10.pdf (дата обращения: 25.12.2018).

5. Sloter L. Overview of nanotechnology nanomanufacturing within the Department of defense. American Vacuum Society International Symposium and Exhibition Baltimore, Maryland. USA. 2014. URL: https://avs.org/AVS/files/d3/d388692a-70b1-472dbec6-44df3b06126e.pdf

6. Tomar S. Nanotechnology: the emerging field for future military applications. IDSA Monograph Series No. 48. 2015. ISBN: 978-93-82169-58-1.

7. Snakes and ladders - Brazil's COBRA future soldier programme. 2014. URL: https://www.defence-andsecurity.com/features/featuresnakes-and-ladders-brazilscobra-4483929/

8. An H., Li M., Gao J. et al. Incorporation of biomolecules in metal-organic frameworks for advanced applications // Coord. Chem. Rev. 2019. V. 384. P. 90-106. https://doi.org/10.1016/j.ccr.2019.01.001

9. Li M., Li D., O’Keeffe M., Yaghi O.M. Topological analysis of metal-organic frameworks with polytopic linkers and/or multiple building units and the minimal transitivity principle // Chem. Rev. 2014. V. 114. № 2. P. 1343-1370. https://doi.org/10.1021/cr400392k

10. Lee Y.-R., Kim J., Ahn W.-S. Synthesis of metalorganic frameworks: a mini review // Korean J. Chem. Eng. 2013. V. 30. № 9. P. 1667-1680. https://doi.org/10.1007/ s11814-013-0140-6

11. Bobbitt N.S., Mendonca M.L., Howarth A.J. et al. Metal-organic frameworks for removal of toxic industrial chemicals and chemical warfare agents // Chem. Soc. Rev. 2017. V. 46. № 11. P. 3357-3385. https://doi.org/10.1039/ $\mathrm{C} 7 \mathrm{CS} 00108 \mathrm{H}$

12. Gutov O.V., Bury W., Gomez-Gualdron D.A. et al. A highly stable zirconium-based metal-organic framework material with high surface area and gas storage capacities // Chem.-Eur. J. 2014. V. 20. № 39. P. 12389-12393. https://doi. org/10.1002/chem.201402895

13. Furukawa H., Cordova K.E., O'Keeffe M., Yaghi O.M. The chemistry and applications of metalorganic frameworks // Science. 2013. V. 341. № 6149. e12340444. https://doi.org/10.1126/science.1230444

14. Project final report № 228604 Nanoporous metal-organic frameworks for production (nano MOF). FP7-NMP-2008-LARGE-2 Project's coordinator: Dr. Wulf Grählert, Fraunhofer IWS. (01/06/1009-30/05/ 2013). URL: https://cordis.europa.eu/docs/results/228604/ finall-nanomof-finai-report-final.pdf (дата обращения: 25.12.2018)

15. USA Patent № 8647419 B2 (2014).

16. Howarth A.J., Liu Y., Li P. et al. Chemical, thermal and mechanical stabilities of metal-organic fameworks // Nat. Rev. Mater. 2016. V. 1. P. e15018. https://doi.org/10.1038/ natrevmats. 2015.18

17. De Coste J.B., Peterson G.W. Metal-organic frameworks for air purification of toxic chemicals // Chem. Rev. 2014. V. 114. № 11. P. 5695-5727. https://doi. org/10.1021/cr4006473

18. Planas N., Mondloch J.E., Tussupbayev S. et al. Defining the proton topology of the Zr6-based metalorganic framework NU-1000 // J. Phys. Lett. 2014. V. 5. № 21. P. 3716-3723. https://doi.org/10.1021/jz501899j

19. Lopes-Maya E., Montoro C., Rodrigues-Albelo L.M. et al. Textile/metal-organic-framework composites as self-detoxifying filters for chemical-warfare agents // Angew. Chem. Int. Edit. 2015. V. 54. № 23. P. 6790-6794. https://doi.org/10.1002/anie.201502094

20. Moon S-Y., Liu Y., Hupp J.T., Farha O.K. Instantaneous hydrolysis of nerve-agent simulants with a six-connected zirconium-based metal-organic framework // Angew. Chem. Int. Edit. 2015. V. 54. № 23. P. 6795-6799. https://doi.org/10.1002/anie.201502155

21. Vemuri R.S., Armatis P.D., Bontha J.R. et al. An overview of detection and neutralization of chemical warfare agents using metal organic frameworks // J. Bioterror. Biodef. 2015. V. 6. № 3. P. el37. https://doi. org/10.4172/2157-2526.1000137

22. Ahmed T., Imdad S., Yaldram K. et al. Emerging nanotechnology-based methods for water purification: a review // Desal. Water Treat. 2013. V. 52. № 22-24. P. 40894101. https://doi.org/10.1080/19443994.2013.801789

23. Alongi J., Tata J., Carosio F. et al. A comparative analysis of nanoparticle adsorption as fire-protection approach for fabrics // Polymers. 2015. V. 7. № 1. P. 47-68. https://doi.org/10.3390/polym7010047

24. Bhuiyan M.A.R., Wang L., Shaid A. et al. Advances and application of chemical protective clothing system // J. Ind. Text. 2019. V. 49. № 1. P. 97-138. https://doi. org/10.1177/1528083718779426

25. Ramaratnam K., Iyer S.K., Kinnan M.K. et al. Ultrahydrophobic textiles using nanoparticles: lotus approach // J. Eng. Fiber. Fabr. 2008. V. 3. № 4. https://doi. org/10.1177/155892500800300402

26. Qi K., Wang X., Xin J.H. Photocatalytic selfcleaning textiles based on nanocrystalline titanium dioxide // Text. Res. J. 2011. V. 81. № 1. P. 101-110. https://doi. org/10.1177/0040517510383618

27. Ugur Ş.S., Sariişik M., Aktaş A.H. The fabrication of nanocomposite thin films with $\mathrm{TiO} 2$ nanoparticles by the layer-by-layer deposition method for multifunctional cotton fabrics // Nanotechnology. 2010. V. 21. № 32. P.e325603.https://doi.org/10.1088/0957-4484/21/32/325603

28. Navale G.R., Thripuranthaka M., Late D.J., Shinde S.S. Antimicrobial activity of $\mathrm{ZnO}$ nanoparticles against pathogenic bacteria and fungi // JSM Nanotechnol. Nanomed. 2015. V. 3. № 1. P. e1033. https://www.jscimedcentral.com/Nanotechnology/ nanotechnology-3-1033.pdf

29. Pei Z., Ma X., Ding P. et al. Study of a QCM dimethyl methylphosphonate sensor based on a $\mathrm{ZnO}$ - 
modified nanowire-structured manganese dioxide film // Sensors (Basel). 2010. V. 10. № 9. P. 8275-8290. https:// dx.doi.org/10.3390/s100908275

30. Jones N., Ray B., Ranjit K.T., Manna A.C. Antibacteral activity of $\mathrm{ZnO}$ nanoparticle suspensions on a broad spectrum of microorganisms // FEMS Microbiol. Lett. 2018. V. 279. № 1. P. 71-76. https://doi.org/10.1111/ j.1574-6968.2007.01012.x

31. Smiechowicz E., Niecraszewicz B., Kulpinski P., Dzitko K. Antibacterial composite cellulose fibers modified with silver nanoparticles and nanosilica // Cellulose. 2018. V. 25. № 6. P. 3499-3517. https://doi.org/10.1007/s10570018-1796-1

32. Gold K., Slay B., Knachstedt M., Gaharwar A.K. Antimicrobial activity of metal and metal-oxide based nanoparticles // Adv. Ther. 2018. V. 1. № 3. P. e1700033. https://doi.org/10.1002/adtp.201700033

33. Xie Y., He Y., Irwin P.L. et al. Antibacterial activity and mechanism of action zinc oxide nanoparticles against Campylobacter jejuni // Appl. Environ. Microbiol. 2011. V. 77. № 7. P. 2325-2331. https://doi.org/10.1128/AEM.02149-10

34. USA Patent № 7534453 B1 (2009).

35. Щербаков А.Б., Жолобак Н.М., Иванов В.К. с соавт. Наноматериалы на основе диоксида церия; свойства и перспективы использования в биологии и медицине // Биотехнология. 2011. Т 4. № 1. С. 9-28.

Shcherbakov A.B., Zholobak N.M., Ivanov V.K. et al. Nanomaterials based on the nanocrystalline ceria: properties and use perspectives in biology and medicine // Biotechnology. 2011. V 4. № 1. P. 9-28 (in Russian).

36. Ravikumar S., Gokulakrishnan R. The inhibitory effect of metal oxide nanoparticles against poultry pathogens // Int. J. Pharm. Sci. Drug Res. 2012. V. 4. № 2. P. $157-159$.

37. Gordon W.O. Metal oxide nanoparticles: optical properties and interaction with chemical warfare agent simulants. Dis. Ph.D. Blacksburg, Virginia, USA. 2006.

38. Doskocz N., Zaleska-Radziwill M. Effects of zirconium oxide nanoparticles on bacterial growth // $\mathrm{PhD}$ Interdiscipl. J. 2015. № 1. P. 161-166.

39. Kim S., Ying W.B., Jung H. et al. Zirconium hydroxide-coated nanofibers mats for nerve agent decontamination // Chem. Asian J. 2017. V. 12. № 6. P. 698705. https://doi.org/10.1002/asia.201601729

40. Prasad S., Roy I. Converting Enzymes into tools of industrial importance // Recent Pat. Biotechnol. 2018. V. 12. № 1. P. 33-56. https://doi.org/10.2174/1872208311666 170612113303

41. Lei Z., Gao C., Chen L. et al. Recent advances in biomolecule immobilization based on self-assembly: organic-inorganic hybrid nanoflowers and metal-organic frameworks as novel substrates // J. Mater. Chem. B. 2018. V. 6. № 11. P. 1581-1594. https://doi.org/10.1039/ C7TB03310A

42. Nguyen H.H., Kim M. An overview of techniques in enzyme immobilization // Appl. Sci. Converg. Technol. 2017. V. 26. № 6. P. 157-163. https://doi.org/10.5757/ ASCT.2017.26.6.157

43. Hartmann M., Kostrov X. Immobilization of enzymes on porous silicas - benefits and challenges // Chem. Soc. Rev. 2013. V. 42. № 15. P. 6277-6289. https://doi. org/10.1039/C3CS60021A

44. Magner E. Immobilisation of enzymes on mesoporous silicate materials // Chem. Soc. Rev. 2013. V. 42. № 15. P. 6213-6222. https://doi.org/10.1039/C2CS35450K

45. Hudson S., Cooney J., Magner E. Proteins in mesoporous silicates // Angew. Chem. Int. Edit. 2008. V. 47. № 45. P. 8582-8594. https://doi.org/10.1002/anie.200705238.

46. Kumar S., Kumar D., Ahirwar R., Nahar P. Exploring the flexible chemistry of 4-fluoro-3-nitrophenyl azide for biomolecule immobilization and bioconjugation // Anal. Bioanal. Chem. 2016. V. 408. № 25. P. 6945-6956. https://doi.org/10.1007/s00216-016-9803-6

47. Jiang H., Xu F.-J. Biomolecule-functionalized polymer brushes // Chem. Soc. Rev. 2013. V. 42. № 8. P. 3394-3426. https://doi.org/10.1039/c2cs35453e

48. Nelson J., Griffin E.G. Adsorption of invertase // J. Am. Chem. Soc. 1916. V. 38. № 5. P. 1109-1115. https://doi. org/10.1021/ja02262a018

49. Lian X., Fang Y., Joseph E. et al. Enzyme-MOF (metal-organic framework) composites // Chem. Soc. Rev. 2017. V. 46. № 11. P. 3386-3401. https://doi.org/10.1039/ c7cs00058h

50. Torres-Salas P., del Monte-Martinez A., CutinoAvila B. et al. Immobilized biocatalysts: novel approaches and tools for binding enzymes to supports // Adv. Mater. 2011. V. 23. № 44. P. 5275-5282. https://doi.org/10.1002/ adma.201101821

51. Li B., Wen H.-M., Cui Y. et al. Emerging multifunctional metal-organic framework materials // Adv. Mater. 2016. V. 28. № 40. P. 8819-8860. https://doi. org/10.1002/adma.201601133

52. Nandasiri M.I., Jambovane S.R., McGrail B.P. et al. Adsorption, separation, and catalytic properties of densified metal-organic frameworks // Coord. Chem. Rev. 2016. V. 311. P. 38-52. https://doi.org/10.1016/j. ccr.2015.12.004

53. Cui Y., Li B., He H. et al. Metal-organic frameworks as platforms for functional materials // Acc. Chem. Res. 2016. V. 49. № 3. P. 483-493. https://doi.org/10.1021/acs. accounts.5b00530

54. Zhu Q.-L., Xu Q. Metal-organic framework composites // Chem. Soc. Rev. 2014. V. 43. № 16. P. 54685512. https://doi.org/10.1039/c3cs60472a

55. Meek S.T., Greathouse J.A., Allendorf M.D. Metalorganic frameworks: a rapidly growing class of versatile nanoporous materials // Adv. Mater. 2011. V. 23. № 2. P. 249-267. https://doi.org/10.1002/adma.201002854

56. Zhou H.-C., Long J.R., Yaghi O.M. Introduction to metal-organic frameworks // Chem. Rev. 2012. V. 112. № 2. P. 673-674. https://doi.org/10.1021/cr300014x

57. Xu M., Yang S.-S., Gu Z.-Y. Two-dimensional metal-organic framework nanosheets: a rapidly growing class of versatile nanomaterials for gas separation, MALDITOF matrix and biomimetic applications // Chem.-Eur. J. 2018. V. 24. № 57. P. 15131-15142. https://doi.org/10.1002/ chem. 201800556

58. Li S., Dharmarwardana M., Welch R.P. et al. 
Template-directed synthesis of porous and protective core-shell bionanoparticles // Angew. Chem. Int. Edit. 2016. V. 55. № 36. P. 10691-10696. https://doi.org/10.1002/ anie. 201604879

59. Anderson S.L., Stylianou K.C. Biologically derived metal organic frameworks // Coord. Chem. Rev. 2017. V.349. P. 102-128.http://dx.doi.org/10.1016/j.ccr.2017.07.012

60. Gkaniatsou E., Sicard C., Ricoux R. et al. Metalorganic frameworks: a novel host platform for enzymatic catalysis and detection // Mater. Horiz. 2017. V. 4. № 1. P. 55-63. https://doi.org/10.1039/C6MH00312E

61. Zhuang J., Young A.P., Tsung C.-K. Integration of biomolecules with metal-organic frameworks // Small. 2017. V. 13. № 32. P. e1700880. https://doi.org/10.1002/ smll.201700880

62. Mehta J., Bhardwaj N., Bhardwaj S.K. et al. Recent advances in enzyme immobilization techniques: metal-organic frameworks as novel substrates // Coord. Chem. Rev. 2016. V. 322. P. 30-40. https://doi.org/10.1016/j. ccr.2016.05.007

63. Cui J., Ren S., Sun B., Jia S. Optimization protocols and improved strategies for metal-organic frameworks for immobilizing enzymes: current development and future challenges // Coord. Chem. Rev. 2018. V. 370. P. 22-41. https://doi.org/10.1016/j.ccr.2018.05.004

64. Zhu X., Zheng H., Wei X. et al. Metal-organic framework (MOF): a novel sensing platform for biomolecules // Chem. Commun. 2013. V. 49. № 13. P. 1276 1278. https://doi.org/10.1039/c2cc36661d

65. Wang Q., Lian X., Fang Y., Zhou H.-C. Applications of immobilized bio-catalyst in metal-organic frameworks // Catalysts. 2018. V. 8. № 4. P. e166. https://doi. org/10.3390/catal8040166

66. Wu X., Hou M., Ge J. Metal-organic frameworks and inorganic nanoflowers: a type of emerging inorganic crystal nanocarrier for enzyme immobilization // Catal. Sci. Technol. 2015. V. 5. № 12. P. 5077-5085. https://doi. org/10.1039/C5CY01181G

67. Chen L., Luque R., Li Y. Controllable design of tunable nanostructures inside metal-organic frameworks // Chem. Soc. Rev. 2017. V. 46. № 15. P. 4614-4630. https:// doi.org/10.1039/c6cs00537c

68. Pang S., Wu Y., Zhang X. et al. Immobilization of laccase via adsorption onto bimodal mesoporous $\mathrm{Zr}-\mathrm{MOF}$ // Process Biochem. 2016. V. 51. № 2. P. 229-239. https://doi. org/10.1016/j.procbio.2015.11.033

69. Lian X., Chen Y.-P., Liu T.-F., Zhou H.-C. Coupling two enzymes into a tandem nanoreactor utilizing a hierarchically structured MOF // Chem. Sci. 2016. V. 7. № 12. P. 6969-6973. https://doi.org/10.1039/c6sc01438k.

70. Lian X., Huang Y., Zhu Y. et al. Enzyme-MOF Nanoreactor activates nontoxic paracetamol for cancer therapy // Angew. Chem. Int. Edit. 2018. V. 57. № 20. P. 5725-5730. https://doi.org/10.1002/anie.201801378

71. Patra S., Crespo T.H., Permyakova A. et al. Design of metal organic framework-enzyme based bioelectrodes as a novel and highly sensitive biosensing platform // J. Mater. Chem. B. 2015. V. 3. № 46. P. 8983-8992. https:// doi.org/10.1039/c5tb01412c
72. Lykourinou V., ChenY., Wang X.-S. et al. Immobilization of MP-11 into a mesoporous metalorganic framework, MP-11@mesoMOF: a new platform for enzymatic catalysis // J. Am. Chem. Soc. 2011. V. 133. № 27. P. 10382-10385. https://doi.org/10.1021/ja2038003

73. Feng D., Liu T.-F., Su J. et al. Stable metal-organic frameworks containing single-molecule traps for enzyme encapsulation // Nat. Commun. 2015. V. 6. P. e5979. https:// doi.org/10.1038/ncomms6979

74. Lian X., Erazo-Oliveras A., Pellois J.-P., Zhou H.-C. High efficiency and long-term intracellular activity of an enzymatic nanofactory based on metalorganic frameworks // Nat. Commun. 2017. V. 8. P. e2075. https://doi.org/10.1038/s41467-017-02103-0

75. Wang C., Gao J., Tan H. Integrated antibody with catalytic metal-organic framework for colorimetric immunoassay // ACS Appl. Mater. Interfaces. 2018. V. 10. № 30. P. 25113-25120. https://doi.org/10.1021/ acsami.8b07225

76. Bhardwaj S.K., Bhardwaj N., Mohanta G.C. et al. Immunosensing of atrazine with antibody-functionalized $\mathrm{Cu}-\mathrm{MOF}$ conducting thin films // ACS Appl. Mater. Interfaces. 2015. V. 7. № 47. P. 26124-26130. https://doi. org/10.1021/acsami.5b07692

77. Kempahanumakkagari S., Kumar V., Samaddar P. et al. Biomolecule-embedded metal-organic frameworks as an innovative sensing platform // Biotechnol. Adv. 2018. V. 36. № 2. P. 467-481. https://doi.org/10.1016/j. biotechadv.2018.01.014

78. Ikezoe Y., Fang J., Wasik T.L. et al. Peptide assembly-driven metal-organic framework (MOF) motors for micro electric generators // Adv. Mater. 2015. V. 27. № 2. P. 288-291. https://doi.org/10.1002/adma.201404273

79. Hintz H., S. Wuttke S. Postsynthetic modification of an amino-tagged MOF using peptide coupling reagents: a comparative study // Chem. Commun. 2014. V. 50. № 78. P. 11472-11475. https://doi.org/10.1039/c4cc02650k.

80. Ikezoe Y., Fang J., Wasik T.L. et al. Peptide-metal organic framework swimmers that direct the motion toward chemical targets // Nano Lett. 2015. V. 15. № 6. P. 4019-4023. https://doi.org/10.1021/acs.nanolett.5b00969

81. Morris W., Briley W. E., Auyeung E. et al. Nucleic acid-metal organic framework (MOF) nanoparticle conjugates // J. Am. Chem. Soc. 2014. V. 136. № 20. P. 72617264. https://doi.org/10.1021/ja503215w

82. Wang S., McGuirk C.M., Ross M.B. et al. General and direct method for preparing oligonucleotidefunctionalized metal-organic framework nanoparticles // J. Am. Chem. Soc. 2017. V. 139. № 29. P. 9827-9830. https:// doi.org/10.1021/jacs.7b05633

83. Qiu G.-H., Weng Z.-H., Hu P.-P. et al. Synchronous detection of ebolavirus conserved RNA sequences and ebolavirus-encoded miRNA-like fragment based on a zwitterionic copper(II) metal-organic framework // Talanta. 2018. V. 180. P. 396-402. https://doi.org/10.1016/j. talanta. 2017. 12.045

84. Zhang H.-T., Zhang J.-W., Huang G. et al. An amine-functionalized metal-organic framework as a sensing platform for DNA detection // Chem. Commun. 
2014. V. 50. № 81. P. 12069-12072. https://doi.org/10.1039/ c4cc05571c

85. Li P., Chen Q., Wang T.C. et al. Hierarchically engineered mesoporous metal-organic frameworks toward cell-free immobilized enzyme systems // Chem. 2018. V. 4. № 5. P. 1022-1034. https://doi.org/10.1016/j. chempr.2018.03.001

86. Chen Y., Li P., Modica J.A. et al. Acid-resistant mesoporous metal-organic framework toward oral insulin delivery: protein encapsulation, protection, and release // J. Am. Chem. Soc. 2018. V. 140. № 17. P. 5678-5681. https:// doi.org/10.1021/jacs.8b02089

87. Gkaniatsou E., Sicard C., Ricoux R. et al. Enzyme encapsulation in mesoporous metal-organic frameworks for selective biodegradation of harmful dye molecules // Angew. Chem. Int. Edit. 2018. V. 57. № 49. P. 16141-16146. https://doi.org/10.1002/anie.201811327

88. Li P., Moon S.-Y., Guelta M.A. et al. Encapsulation of a nerve agent detoxifying enzyme by a mesoporous zirconium metal-organic framework engenders thermal and long-term stability // J. Am. Chem. Soc. 2016. V. 138. № 26. P. 8052-8055. https://doi.org/10.1021/jacs.6b03673

89. Zhong Z., Pang S., Wu Y. et al. Synthesis and characterization of mesoporous $\mathrm{Cu}-\mathrm{MOF}$ for laccase immobilization // J. Chem. Technol. Biotechnol. 2017. V. 92. № 7. P. 1841-1847. https://doi.org/10.1002/jctb.5189

90. Pisklak T.J., Macías M., Coutinho D.H. et al. Hybrid materials for immobilization of MP-11 catalyst // Top Catal. 2006. V. 38. № 4. P. 269-278. https://doi. org/10.1007/s11244-006-0025-6

91. Rambabu D., Pooja, Pradeep C.P., Dhir A. A cytochrome $\mathrm{C}$ encapsulated metal organic framework as a bio-material for sulfate ion recognition // J. Mater. Chem. A. 2014. V. 2. № 23. P. 8628-8631.https://doi.org/10.1039/ C4TA01599A

92. Chen W., Yang W., Lu Y. et al. Encapsulation of enzyme into mesoporous cages of metal-organic frameworks for the development of highly stable electrochemical biosensors // Anal. Methods. 2017. V. 9. № 21. P. 3213-3220. https://doi.org/10.1039/C7AY00710H

93. Deng H., Grunder S., Cordova K.E. et al. Largepore apertures in a series of metal-organic frameworks // Science. 2012. V. 336. № 6084. P. 1018-1023. https://doi. org/10.1126/science.1220131

94. Chen Y., Lykourinou V., Hoang T. et al. Sizeselective biocatalysis of myoglobin immobilized into a mesoporous metal-organic framework with hierarchical pore sizes // Inorg. Chem. 2012. V. 51. № 17. P. 9156-9158. https://doi.org/10.1021/ic301280n

95. Kim Y., Yang T., Yun G. et al. Hydrolytic transformation of microporous metal-organic frameworks to hierarchical micro- and mesoporous MOFs // Angew. Chem. Int. Edit. 2015. V. 54. № 45. P. 13273-13278. https:// doi.org/10.1002/anie.201506391

96. Li P., Modica J.A., Howarth A.J. et al. Toward design rules for enzyme immobilization in hierarchical mesoporous metal-organic frameworks // Chem. 2016. V. 1. № 1. P. 154-169. https://doi.org/10.1016/j. chempr.2016.05.001
97. Chen Y., Han S., Li X. et al. Why does enzyme not leach from metal-organic frameworks (MOFs)? Unveiling the interactions between an enzyme molecule and a MOF // Inorg. Chem. 2014. V. 53. № 19. P. 10006-10008. https:// doi.org/10.1021/ic501062r

98. Chen Y., Lykourinou V., Vetromile C. et al. How can proteins enter the interior of a MOF? Investigation of cytochrome $c$ translocation into a MOF consisting of mesoporous cages with microporous windows // J. Am. Chem. Soc. 2012. V. 134. № 32. P. 13188-13191. https://doi. org/10.1021/ja305144x

99. Liu W.-L., Lo S.-H., Singco B. et al. Novel trypsinFITC@MOF bioreactor efficiently catalyzes protein digestion // J. Mater. Chem. B. 2013. V. 1. № 7. P. 928-932. https://doi.org/10.1039/c3tb00257h

100. Liu W.-L., Wu C.-Y., Chen C.-Y. et al. Fast multipoint immobilized MOF bioreactor // Chem.-Eur. J. 2014. V. 20. № 29. P. 8923-8928. https://doi.org/10.1002/ chem. 201400270

101. Liu W.-L., Yang N.-S., Chen Y.-T. et al. Lipasesupported metal-organic framework bioreactor catalyzes warfarin synthesis // Chem.-Eur. J. 2015. V. 21. № 1. P. 115119. https://doi.org/10.1002/chem.201405252

102. Ma W., Jiang Q., Yu P. et al. Zeolitic imidazolate framework-based electrochemical biosensor for in vivo electrochemical measurements // Anal. Chem. 2013. V. 85. № 15. P. 7550-7557. https://doi.org/10.1021/ac401576u

103. Zhang C., Wang X., Hou M. et al. Immobilization on metal-organic framework engenders high sensitivity for enzymatic electrochemical detection // ACS Appl. Mater. Interfaces. 2017. V. 9. № 16. P. 13831-13836. https://doi. org/10.1021/acsami.7b02803

104. Zhang Y., Wang H., Liu J. et al. Enzymeembedded metal-organic framework membranes on polymeric substrates for efficient CO2 capture // J. Mater. Chem. A. 2017. V. 5. № 37. P. 19954-19962. https://doi. org/10.1039/C7TA03719H

105. Qin F.-X., Jia S.-Y., Wang F.-F. et al. Hemin@ metal-organic framework with peroxidase-like activity and its application to glucose detection // Catal. Sci. Technol. 2015. V. 3. № 10. P. 2761-2768. https://doi.org/10.1039/ C3CY00268C

106. Cao Y., Wu Z., Wang T. et al. Immobilization of Bacillus subtilis lipase on a Cu-BTC based hierarchically porous metal-organic framework material: a biocatalyst for esterification // Dalton Trans. 2016. V. 45. № 16. P. 69987003. https://doi.org/10.1039/c6dt00677a

107. Liu G., Xu Y., Han Y. et al. Immobilization of lysozyme proteins on a hierarchical zeolitic imidazolate framework (ZIF-8) // Dalton Trans. 2017. V. 46. № 7. P. 2114-2121. https://doi.org/10.1039/c6dt04582k

108. Lu X., Wang X., Wu L. et al. Response characteristics of bisphenols on a metal-organic frameworkbased tyrosinase nanosensor // ACS Appl. Mater. Interfaces. 2016. V. 8. № 25. P. 16533-16539. https://doi.org/10.1021/ acsami.6b05008

109. Kumar P., Kim K.-H., Bansal V. et al. Practical utilization of nanocrystal metal organic framework biosensor for parathion specific recognition // Microchem. 
J. 2016. V. 128. P. 102-107. https://doi.org/10.1016/j.microc. 2016.04.008

110. Zare A., Bordbar A.-K., Jafarian F., Tangestaninejad S. Candida rugosa lipase immobilization on various chemically modified Chromium terephthalate MIL-101 // J. Mol. Liq. 2018. V. 254. P. 137-144. https://doi. org/10.1016/j.molliq.2018.01.097

111. Jung S., Kim Y., Kim S.-J. et al. Biofunctionalization of metal-organic frameworks by covalent protein conjugation // Chem. Commun. 2011. V. 47. № 10. P. 2904-2906. https://doi.org/10.1039/c0cc03288c

112. Tudisco C., Zolubas G., Seoane B. et al. Covalent immobilization of glucose oxidase on amino MOFs via post-synthetic modification // RSC Adv. 2016. V. 6. № 109. P. 108051-108055. https://doi.org/10.1039/C6RA19976C

113. Wang X., Makal T.A., Zhou H.-C. Protein immobilization in metal-organic frameworks by covalent binding // Aust. J. Chem. 2014. V. 67. № 11. P. 1629-1631. https://doi.org/10.1071/CH14104

114. Shih Y.-H., Lo S.-H., Yang N.-S. et al. Trypsinimmobilized metal-organic framework as a biocatalyst in proteomics analysis // ChemPlusChem. 2012. V. 77. № 11. P. 982-986. https://doi.org/10.1002/cplu.201200186

115. Wang Z., Cohen S.M. Postsynthetic covalent modification of a neutral metal-organic framework // J. Am. Chem. Soc. 2007. V. 129. № 41. P. 12368-12369. https://doi.org/10.1021/ja074366o

116. Kumar P., Deep A., Paul A.K., Bharadwaj L.M. Bioconjugation of MOF-5 for molecular sensing // J. Porous Mater. 2014. V. 21. № 1. P. 99-104. https://doi.org/10.1007/ s10934-013-9752-9

117. Fujita D., Suzuki K., Sato S. et al. Protein encapsulation within synthetic molecular hosts // Nat. Commun. 2012. V. 3. P. e1093. https://doi.org/10.1038/ ncomms2093

118. Patra S., Sene S., Mousty C. et al. Design of laccase-metal organic framework-based bioelectrodes for biocatalytic oxygen reduction reaction // ACS Appl. Mater. Interfaces. 2016. V. 8. № 31. P. 20012-20022. https://doi. org/10.1021/acsami.6b05289

119. Cao S.-L., Yue D.-M., Li X.-H. et al. Novel nano-/ micro-biocatalyst: soybean epoxide hydrolase immobilized on UiO-66-NH2 MOF for efficient biosynthesis of enantiopure (R)-1,2-octanediol in deep eutectic solvents // ACS Sustainable Chem. Eng. 2016. V. 4. № 6. P. 3586-3595. https://doi.org/10.1021/acssuschemeng.6b00777

120. Doherty C.M., Grenci G., Riccò R. et al. Combining UV lithography and an imprinting technique for patterning metal-organic frameworks // Adv. Mater. 2013. V. 25. № 34. P. 4701-4705. https://doi.org/10.1002/ adma.201301383

121. Shieh F.-K., Wang S.-C., Leo S.-Y., Wu K.C.-W. Water-based synthesis of zeolitic imidazolate framework-90 (ZIF-90) with a controllable particle size // Chem.-Eur. J. 2013. V. 19. № 34. P. 11139-11142. https://doi.org/10.1002/ chem. 201301560

122. Jia Z., Wu G., Wu D. et al. Preparation of ultra-stable ZIF-8 dispersions in water and ethanol // J. Porous Mater. 2017. V. 24. № 6. P. 1655-1660. https://doi. org/10.1007/s10934-017-0405-2

123. Cheng H., Zhang L., He J. et al. Integrated nanozymes with nanoscale proximity for in vivo neurochemical monitoring in living brains // Anal. Chem. 2016. V. 88. № 10. P. 5489-5497. https://doi.org/10.1021/acs. analchem.6b00975

124. Cui J., Feng Y., Lin T. et al. Mesoporous metalorganic framework with well-defined cruciate flower-like morphology for enzyme immobilization // ACS Appl. Mater. Interfaces. 2017. V. 9. № 12. P. 10587-10594. https:// doi.org/10.1021/acsami.7b00512

125. Wu X., Ge J., Yang C. et al. Facile synthesis of multiple enzyme-containing metal-organic frameworks in a biomolecule-friendly environment // Chem. Commun. 2015. V. 51. № 69. P. 13408-13411. https://doi.org/10.1039/ c5 $\mathrm{cc} 05136 \mathrm{c}$

126. Hou C., Wang Y., Ding Q. et al. Facile synthesis of enzyme-embedded magnetic metal-organic frameworks as a reusable mimic multi-enzyme system: mimetic peroxidase properties and colorimetric sensor // Nanoscale. 2015. V. 7. № 44. P. 18770-18779. https://doi.org/10.1039/ c5nr04994f

127. Shieh F.-K., Wang S.-C., Yen C.-I et al. Imparting functionality to biocatalysts via embedding enzymes into nanoporous materials by a de novo approach: sizeselective sheltering of catalase in metal-organic framework microcrystals // J. Am. Chem. Soc. 2015. V. 137. № 13. P. 4276-4279. https://doi.org/10.1021/ja513058h

128. Liang K., Ricco R., DohertyC.M.etal.Biomimetic mineralization of metal-organic frameworks as protective coatings for biomacromolecules // Nat. Commun. 2015. V. 6. P. e7240. https://doi.org/10.1038/ncomms 8240

129. Lyu F., Zhang Y., Zare R.N. et al. One-pot synthesis of protein-embedded metal-organic frameworks with enhanced biological activities // Nano Lett. 2014. V. 14. № 10. P. 5761-5765. https://doi.org/10.1021/nl5026419

130. Liao F.-S., Lo W.-S., Hsu Y.-S. et al. Shielding against unfolding by embedding enzymes in metal-organic frameworks via a de novo approach // J. Am. Chem. Soc. 2017. V. 139. № 19. P. 6530-6533. https://doi.org/10.1021/ jacs.7b01794

131. Chen T.-T., Yi J.-T., Zhao Y.-Y., Chu X. Biomineralized metal-organic framework nanoparticles enable intracellular delivery and endo-lysosomal release of native active proteins // J. Am. Chem. Soc. 2018. V. 140. № 31. P. 9912-9920. https://doi.org/10.1021/jacs.8b04457

132. Liang W., Ricco R., Maddigan N.K. et al. Control of structure topology and spatial distribution of biomacromolecules in protein@ZIF-8 biocomposites // Chem. Mater. 2018. V. 30. № 3. P. 1069-1077. https://doi. org/10.1021/acs.chemmater.7b04977

133. Wang C., Sun H., Luan J. et al. Metal-organic framework encapsulation for biospecimen preservation // Chem. Mater. 2018. V. 30. № 4. P. 1291-1300. https://doi. org/10.1021/acs.chemmater.7b04713

134. Liang Z., Yang Z., Yuan H. et al. A protein@ metal-organic framework nanocomposite for $\mathrm{pH}$-triggered anticancer drug delivery // Dalton Trans. 2018. V. 47. № 30. P. 10223-10228. https://doi.org/10.1039/c8dt01789a 
135. Li S., Dharmarwardana M., Welch R.P. et al. Investigation of controlled growth of metal-organic frameworks on anisotropic virus particles // ACS Appl. Mater. Interfaces. 2018. V. 10. № 21. P. 18161-18169. https:// doi.org/10.1021/acsami.8b01369

136. Zhang M., Gu Z.-Y., Bosch M. et al. Biomimicry in metal-organic materials // Coord. Chem. Rev. 2015. V. 293294. P. 327-356. https://doi.org/10.1016/j.ccr.2014.05.031

137. Rojas S., Devic T., Horcajada P. Metal organic frameworks based on bioactive components // J. Mater. Chem. B. 2017. V. 5. № 14. P. 2560-2573. https://doi. org/10.1039/c6tb03217f

138. Oh H., Li T., An J. Drug Release Properties of a series of adenine-based metal-organic frameworks // Chem.-Eur. J. 2015. V. 21. № 47. P. 17010-17015. https://doi. org/10.1002/chem.201501560

139. An J., Farha O.K., Hupp J.T. et al. Metal-adeninate vertices for the construction of an exceptionally porous metal-organic framework // Nat. Commun. 2012. V. 3. P. e604. https://doi.org/10.1038/ncomms1618

140. Amo-Ochoa P., Zamora F. Coordination polymers with nucleobases: From structural aspects to potential applications // Coord. Chem. Rev. 2014. V. 276. P. 34-58. https://doi.org/10.1016/j.ccr.2014.05.017

141. An J., Geib S.J., Rosi N.L. Cation-triggered drug release from a porous zinc-adeninate metal-organic framework // J. Am. Chem. Soc. 2009. V. 131. № 24. P. 8376-8377. https://doi.org/10.1021/ja902972w

142. Li T., Kozlowski M.T., Doud E.A. et al. Stepwise ligand exchange for the preparation of a family of mesoporous MOFs // J. Am. Chem. Soc. 2013. V. 135. № 32. P. 11688-11691. https://doi.org/10.1021/ja403810k

143. Zhang M., Lu W., Li J.-R. et al. Design and synthesis of nucleobase-incorporated metal-organic materials // Inorg. Chem. Front. 2014. V. 1. № 2. P. 159-162. https://doi.org/10.1039/C3QI00042G

144. Saunders C.D.L., Burford N., Werner-Zwanziger U., McDonald R. Preparation and Comprehensive Characterization of $\left[\mathrm{Hg}_{6}(\text { Alanine })_{4}\left(\mathrm{NO}_{3}\right)_{4}\right] \cdot \mathrm{H}_{2} \mathrm{O}$ // Inorg. Chem. 2008. V. 47. № 9. P. 3693-3699. https://doi. org/10.1021/ic702321d

145. Rabone J., Yue Y.-F., Chong S.Y. et al. An adaptable peptide-based porous material // Science. 2010. V. 329. № 5995. P. 1053-1057. https://doi.org/10.1126/ science. 1190672

146. Katsoulidis A.P., Park K.S., Antypov D. et al. Guest-adaptable and water-stable peptide-based porous materials by imidazolate side chain control // Angew. Chem. Int. Edit. 2014. V. 53. № 1. P. 193-198. https://doi. org/10.1002/anie.201307074

147. Majewski M.B., Howarth A.J., Li P. et al. Enzyme encapsulation in metal-organic frameworks for applications in catalysis // CrystEngComm. 2017. V. 19. № 29. P. 4082-4091. https://doi.org/10.1039/C7CE00022G

148. Chulkaivalsucharit P., Wu X., Ge J. Synthesis of enzyme-embedded metal-organic framework nanocrystals in reverse micelles // RSC Adv. 2015. V. 5. № 123. P. $101293-$ 101296. https://doi.org/10.1039/C5RA21069K

149. Tadepalli S., Yim J., Cao S. et al. Metal-
Organic framework encapsulation for the preservation and photothermal enhancement of enzyme activity // Small. 2018. V. 14. P. e1702382. https://doi.org/10.1002/ smll.201702382.

150. Xu Z., Xiao G., Li H. et al. Compartmentalization within self-assembled metal-organic framework nanoparticles for tandem reactions // Adv. Funct. Mater. 2018. V. 28. № 34. P. e1802479. https://doi.org/10.1002/ adfm.201802479

151. Jeong G.-Y., Ricco R., Liang K. et al. Bioactive MIL-88A framework hollow spheres via interfacial reaction in-droplet microfluidics for enzyme and nanoparticle encapsulation // Chem. Mater. 2015. V. 27. № 23. P. 79037909. https://doi.org/10.1021/acs.chemmater.5b02847

152. Rafiei S., Tangestaninejad S., Horcajada P. et al. Efficient biodiesel production using a lipase@ZIF-67 nanobioreactor // Chem. Eng. J. 2018. V. 334. P. 1233-1241. http://dx.doi.org/10.1016/j.cej.2017.10.094

153. Hu Y., Dai L., Liu D., Du W. Rationally designing hydrophobic UiO-66 support for the enhanced enzymatic performance of immobilized lipase // Green Chem. 2018. V. 20. № 19. P. 4500-4506. https://doi.org/10.1039/ C8GC01284A.

154. Pitzalis F., Carucci C., Naseri M. et al. Lipase Encapsulation onto ZIF-8: a comparison between biocatalysts obtained at low and high zinc/2methylimidazole molar ratio in aqueous medium // ChemCatChem. 2018. V. 10. № 7. P. 1578-1585. https://doi. org/10.1002/cctc.201701984

155. Shi L., Cai X., Li H. et al. ZIF-67 Derived porous carbon from calcination and acid etching process as an enzyme immobilization platform for glucose sensing // Electroanalysis. 2018. V. 30. № 3. P. 466-473. https://doi. org/10.1002/elan.201700678

156. Liu X., Qi W., Wang Y. et al. Rational design of mimic multienzyme systems in hierarchically porous biomimetic metal-organic frameworks // ACS Appl. Mater. Interfaces. 2018. V. 10. № 39. P. 33407-33415. https://doi. org/10.1021/acsami.8b09388

157. Chakrapani V., Ahmed K.B.A., Kumar V.V. et al. A facile route to synthesize casein capped copper nanoparticles: an effective antibacterial agent and selective colorimetric sensor for mercury and tryptophan // RSC Adv. 2014. V. 4. № 63. P. 33215-33221. https://doi. org/10.1039/C4RA03086A

158. Yin Y., Gao C., Xiao Q. et al. Protein-Metal Organic framework hybrid composites with intrinsic peroxidase-like activity as a colorimetric biosensing platform // ACS Appl. Mater. Interfaces. 2016. V. 8. № 42. P. 29052-29061. https://doi.org/10.1021/acsami.6b09893

159. Liu X., Qi W., Wang Y. et al. A facile strategy for enzyme immobilization with highly stable hierarchically porous metal-organic frameworks // Nanoscale. 2017. V. 9. № 44. P. 17561-17570. https://doi.org/10.1039/c7nr06019j.

160. Wang X., Lu X., Wu L., Chen J. 3D metalorganic framework as highly efficient biosensing platform for ultrasensitive and rapid detection of bisphenol A // Biosens. Bioelectron. 2015. V. 65. P. 295-301. https://doi. org/10.1016/j.bios.2014.10.010. 
161. Xie S., Ye J., Yuan Y. et al. A multifunctional hemin@metal-organic framework and its application to construct an electrochemical aptasensor for thrombin detection // Nanoscale. 2015. V. 7. № 43. P. 18232-18238. https://doi.org/10.1039/C5NR04532K.

162. Shen W.-J., Zhuo Y., Chai Y.-Q., Yuan R. Cubased metal-organic frameworks as a catalyst to construct a ratiometric electrochemical aptasensor for sensitive lipopolysaccharide detection // Anal. Chem. 2015. V. 87. № 22. P. 11345-11352. https://doi.org/10.1021/acs. analchem.5b02694

163. Dong S., Zhang D., Suo G. et al. Exploiting multi-function metal-organic framework nanocomposite Ag@Zn-TSA as highly efficient immobilization matrixes for sensitive electrochemical biosensing // Anal. Chim. Acta. 2016. V. 934. P. 203-211. https://doi.org/10.1016/j. aca.2016.05.040

164. Dong S., Peng L., Wei W., Huang T. Three MOFTemplated carbon nanocomposites for potential platforms of enzyme immobilization with improved electrochemical performance // ACS Appl. Mater. Interfaces. 2018. V. 10. № 17. P. 14665-14672. https://doi.org/10.1021/ acsami.8b00702

165. Zhang X., Zeng Y., Zheng A. et al. A fluorescence based immunoassay for galectin- 4 using gold nanoclusters and a composite consisting of glucose oxidase and a metalorganic framework // Microchim Acta. 2017. V. 184. № 7. P. 1933-1940. https://doi.org/10.1007/s00604-017-2204-5

166. Gong C., Shen Y., Chen J. et al. Microperoxidase-11@PCN-333 (Al)/three-dimensional macroporous carbon electrode for sensing hydrogen peroxide // Sensor. Actuat. B-Chem. 2017. V. 239. P. 890897. https://doi.org/10.1016/j.snb.2016.08.108

167. Ling P., Lei J., Zhang L., Ju H. Porphyrinencapsulated metal-organic frameworks as mimetic catalysts for electrochemical DNA sensing via allosteric switch of hairpin DNA // Anal. Chem. 2015. V. 87. № 7. P.3957-3963.https://doi.org/10.1021/acs.analchem.5b00001

168. Chen J., Yu C., Zhao Y. et al. A novel noninvasive detection method for the FGFR3 gene mutation in maternal plasma for a fetal achondroplasia diagnosis based on signal amplification by hemin-MOFs/PtNPs // Biosens. Bioelectron. 2017. V. 91. P. 892-899. https://doi. org/10.1016/j.bios.2016.10.067

169. Wu Y., Han J., Xue P. et al. Nano metal-organic framework (NMOF)-based strategies for multiplexed microRNA detection in solution and living cancer cells // Nanoscale. 2015. V. 7. № 5. P. 1753-1759. https://doi. org/10.1039/c4nr05447d

170. Shen X., Yan B. A novel fluorescence probe for sensing organic amine vapors from a Eu3 $+\beta$-diketonate functionalized bio-MOF-1 hybrid system // J. Mater. Chem. C. 2015. V. 3. № 27. P. 7038-7044. https://doi.org/10.1039/ C5TC01287B

171. Shen X., Yan B. Photofunctional hybrids of lanthanide functionalized bio-MOF-1 for fluorescence tuning and sensing // J. Colloid Interf. Sci. 2015. V. 451. P. 63-68. https://doi.org/10.1016/j.jcis.2015.03.039

172. Weng H., Yan B. A Eu(III) doped metal-organic framework conjugated with fluorescein-labeled singlestranded DNA for detection of $\mathrm{Cu}(\mathrm{II})$ and sulfide // Anal. Chim. Acta. 2017. V. 988. P. 89-95. https://doi.org/10.1016/j. aca.2017.07.061

173. Wang X., Yang C., Zhu S. et al. 3D origami electrochemical device for sensitive $\mathrm{Pb} 2+$ testing based on DNA functionalized iron-porphyrinic metal-organic framework // Biosens. Bioelectron. 2017. V. 87. P. 108-115. https://doi.org/10.1016/j.bios.2016.08.016

174. Hu P.-P., Liu N., Wu K.-Y. et al. Successive and specific detection of $\mathrm{Hg} 2+$ and I- by a DNA@MOF biosensor: experimental and simulation studies // Inorg. Chem. 2018. V. 57. № 14. P. 8382-8389. https://doi. org/10.1021/acs.inorgchem.8b01051

175. Horcajada P., Serre C., Vallet-Regí M. et al. Metalorganic frameworks as efficient materials for drug delivery // Angew. Chem. Int. Edit. 2006. V. 45. № 36. P. 5974-5978. https://doi.org/10.1002/anie.200601878

176. He C., Lu K., Liu D., Lin W. Nanoscale metalorganic frameworks for the co-delivery of cisplatin and pooled siRNAs to enhance therapeutic efficacy in drugresistant ovarian cancer cells // J. Am. Chem. Soc. 2014. V. 136. № 14. P. 5181-5184. https://doi.org/10.1021/ja4098862

177. Miller S.R., Heurtaux D., Baati T. et al. Biodegradable therapeutic MOFs for the delivery of bioactive molecules // Chem. Commun. 2010. V. 46. № 25. P. 4526-4528. https://doi.org/10.1039/C001181A

178. Wuttke S., Braig S., Preiß T. et al. MOF nanoparticles coated by lipid bilayers and their uptake by cancer cells // Chem. Commun. 2015. V. 51. № 87. P. 1575215755. https://doi.org/10.1039/c5cc06767g

179. Liu Y., Hou W., Xia L. et al. ZrMOF nanoparticles as quenchers to conjugate DNA aptamers for target-induced bioimaging and photodynamic therapy // Chem. Sci. 2018. V. 9. № 38. P. 7505-7509. https://doi.org/10.1039/c8sc02210k

180. Shen H., Liu J., Lei J., Ju H. A core-shell nanoparticle-peptide@metal-organic framework as $\mathrm{pH}$ and enzyme dual-recognition switch for stepwise-responsive imaging in living cells // Chem. Commun. 2018. V. 54. № 66. P. 9155-9158. https://doi.org/10.1039/c8cc04621b

181. Wang Z., Fu Y., Kang Z. et al. Organelle-specific triggered release of immunostimulatory oligonucleotides from intrinsically coordinated DNA-metal-organic frameworks with soluble exoskeleton // J. Am. Chem. Soc. 2017. V. 139. № 44. P. 15784-15791. https://doi.org/10.1021/ jacs.7b07895

182. Cheng G., Li W., Ha L. et al. Self-assembly of extracellular vesicle-like metal-organic framework nanoparticles for protection and intracellular delivery of biofunctional proteins // J. Am. Chem. Soc. 2018. V. 140. № 23. P. 7282-7291. https://doi.org/10.1021/jacs.8b03584

183. Uemura T., Yanai N., Kitagawa S. Polymerization reactions in porous coordination polymers // Chem. Soc. Rev. 2009. V. 38. № 5. P. 1228-1236. https://doi.org/10.1039/ b802583p

184. Zhao J., Li H., Han Y. et al. Chirality from substitution: enantiomer separation via a modified metalorganic framework // J. Mater. Chem. A. 2015. V. 3. № 23. P. $12145-12148$ 
185. Navarro-Sánchez J., Argente-García A.I., Moliner-Martínez Y. et al. Peptide metal-organic frameworks for enantioselective separation of chiral drugs // J. Am. Chem. Soc. 2017. V. 139. № 12. P. 4294-4297. https://doi.org/10.1021/jacs.7b00280

186. Ren Z., Luo J., Wan Y. Highly permeable biocatalytic membrane prepared by $3 \mathrm{D}$ modification: Metal-organic frameworks ameliorate its stability for micropollutants removal // Chem. Eng. J. 2018. V. 348. P. 389-398. https://doi.org/10.1016/j.cej.2018.04.203

187. Mon M., Lloret F., Ferrando-Soria J. et al. Selective and efficient removal of mercury from aqueous media with the highly flexible arms of a bioMOF // Angew. Chem. Int. Edit. 2016. V. 55. № 37. P. 11167-11172. https:// doi.org/10.1002/anie.201606015

188. Kahn J.S., Freage L., Enkin N. et al. Stimuliresponsive DNA-functionalized metal-organic frameworks (MOFs) // Adv. Mater. 2017. V. 29. № 6. P. e1602782. https:// doi.org/10.1002/adma.201602782

189. Guo Y., Jiang Z., Ying W. et al. A DNA-Threaded ZIF-8 membrane with high proton conductivity and low methanol permeability // Adv. Mater. 2018. V. 30. № 2. P. e1705155. https://doi.org/10.1002/adma.201705155

190. Liang K., Richardson J.J., Cui J. et al. Metalorganic framework coatings as cytoprotective exoskeletons for living cells // Adv. Mater. 2016. V. 28. № 36. P. 7910-7914. https://doi.org/10.1002/adma.201602335

191. Liang K., Richardson J.J., Doonan C.J. et al. An enzyme-coated metal-organic framework shell for synthetically adaptive cell survival // Angew. Chem. Int. Edit. 2017. V. 56. № 29. P. 8510-8515. https://doi.org/10.1002/ anie. 201704120

192. Feng Y., Wang H., Zhang S. et al. Antibodies@ MOFs: an In Vitro protective coating for preparation and storage of biopharmaceuticals // Adv. Mater. 2019. V. 31. № 2. e1805148. https://doi.org/10.1002/adma.201805148

\section{Об авторах}

Федеральное государственное бюджетное учреждение «27 Научный центр» Министерства обороны Российской Федерации - Организация, представляющая условия для реализации Проекта, 105005, Российская Федерация, г. Москва, Бригадирский пер., д. 13.

Завьялов Василий Владимирович. Старший научный сотрудник, канд. хим. наук, проф. АВН, член научного коллектива, выполняющего грант.

Завьялова Наталья Васильевна. Главный научный сотрудник, д-р. биол. наук, проф., академик АВН, руководитель научного коллектива, выполняющего грант.

Холстов Виктор Иванович. Член дис. совета на базе 27 НЦ МО РФ, д-р хим. наук, проф., почетный химик РФ, акад. РАЕН и АВН, член-корр. РАР и АН.

ООО «Научно-исследовательский институт эластомерных материалов и изделий», Российская Федерация, 111024, г. Москва, Перовский проезд, д. 2, стр. 1.

Гореленков Валентин Константинович. Ведущий научный сотрудник, д-р хим. наук, проф., член научного коллектива, выполняющего грант.

Национальный исследовательский технологический университет «МИСиС», 119049, Российская Федерация, г. Москва, Ленинский проспект, д. 4.

Фролов Георгий Александрович. Доцент кафедры, канд. хим. наук, доцент, член научного коллектива, выполняющего грант.

Московский государственный университет имени М.В. Ломоносова, химический факультет, 119991, Российская Федерация, г. Москва, Ленинские горы, д. 1, стр. 3.

Лягин Илья Владимирович. Старший научный сотрудник, канд. хим. наук, член научного коллектива, выполняющего грант.

Еøременко Елена Николаевна. Зав. лабораторией, д-р. биол. наук, проф., член научного коллектива, выполняющего грант.

Контактная информация для всехавторов: 27nc_1@mil.ru Контактное лицо: Завьялова Наталья Васильевна; 27nc_1@mil.ru 


\title{
Strategy for Development of Modern Protective Equipment Based on Organometallic Complexes with Desired Properties
}

\author{
V.V. Zavyalov' ${ }^{1}$, N.V. Zavyalova ${ }^{1}$, V.I. Kholstov' ${ }^{1}$, V.K. Gorelenkov², \\ G.A. Frolov³, I.V. Lyagin ${ }^{4}$, E.N. Efremenko ${ }^{4}$
}

${ }^{1}$ Federal State Budgetary Establishment «27 Scientific Centre» of the Ministry of Defence of the Russian Federation. Brigadirskii Lane 13, Moscow 105005, Russian Federation

2Limited Liability Company «Scientific Research Institute of Elastomer Materials and
Products». Perovsky Passage 2, Moscow 111024, Russian Federation ${ }^{3}$ National University of Science and Technology MISIS. Leninsky Avenue 4,
Moscow 119049, Russian Federation

\section{${ }^{4}$ Lomonosov Moscow State University, Faculty of Chemistry. Lenin Hills 1-3, Moscow 119991, Russian Federation}

\begin{abstract}
The aim of this review is to analyze the existing approaches to the creation and the improvement of materials and fabrics based on metal-organic frameworks (MOFs), which can be the basis for developing a strategy for creating modular MOF materials for modern personal protective equipment (PPE) against toxic chemicals and pathogenic microorganisms. The review provides the details of the use of biomolecules for integration with MOF by pore encapsulation, surface attachment, covalent binding, in situ encapsulation of biomolecules in MOF, and the creation of bio-MOFs. The characteristics of biomolecules that can be included in MOFs are presented. Certain schemes for the inclusion of some biomolecules in MOFs are given. The main properties of MOFs, the main trends of their creation, as well as the most promising directions of application of biomolecules/MOF composites are discussed. The strategy of the creation of modular MOF materials with desired properties for modern PPE, that provide protection against various hazards of chemical, biological and physical nature, is presented. The main trends of the development of modern PPE based on modular MOF materials with desired properties are given. Particular schemes of the creation of separate modules in MOF structures, as well as the determination of their importance and significance for imparting universal protective properties to MOF materials are proposed.
\end{abstract}

Keywords: biomolecules in metal-organic frameworks; protective materials and fabrics; biomolecules/ MOF composites; organometallic complexes with desired properties; organometallic complexes; modular MOF materials; specific properties - self-degassing and bactericidal action.

For citation: Zavyalov V.V., Zavyalova N.V., Kholstov V.I., Gorelenkov V.K., Frolov G.A., Lyagin I.V., Efremenko E.N. Strategy for Development of Modern Protective Equipment Based on Organometallic Complexes with Desired Properties // Journal of NBC Protection Corps. 2020. V. 4. № 3. P. 305-337. https://doi.org/10.35825/2587-5728-2020-4-3-305-337

This work was carried out with the financial support of the Russian Foundation for Basic Research (RFBR) (Grant № 18-29-17069).

\section{Conflict of interest statement}

The authors declare that the research was conducted in the absence of any commercial or financial relationship that could be construed as a potential conflict of interest.

Peer review information

The article has been peer reviewed by two experts in the respective field. Peer reviews are available from the Editorial Board and from Russian Science Citation Index database. 
Authors

Federal State Budgetary Establishment «27 Scientific Centre» of the Ministry of Defence of the Russian Federation. Brigadirskii Lane 13, Moscow 105005, Russian Federation.

Vasily Vladimirovich Zavyalov. Senior Researcher. Candidate of Chemical Sciences. Professor of the Academy of Military Sciences.

Natalya Vasilyevna Zavyalova. Leading Researcher. Doctor of Biological Sciences, Professor. Academician of the Academy of Military Sciences.

Viktor Ivanovich Kholstov. Member of the Dissertation Council of the 27 Scientific Centre of the Ministry of Defence of the Russian Federation. Doctor of Chemical Sciences, Professor. Honored Chemist of the Russian Federation. Academician of the Russian Academy of Natural Sciences and the Academy of Military Sciences. Corresponding Member of the Russian Academy of Sciences and the Russian Academy of Rocket and Artillery Sciences.

Limited Liability Company «Scientific Research Institute of Elastomer Materials and Products». Perovsky Passage 2, Moscow 111024, Russian Federation.

Valentin Konstantinovich Gorelenkov. Leading Researcher. Doctor of Chemical Sciences, Professor.

National University of Science and Technology MISIS. Leninsky Avenue 4, Moscow 119049, Russian Federation.

George Alexandrovich Frolov. Candidate of Chemical Sciences, Associate Professor.

Lomonosov Moscow State University, Faculty of Chemistry. Lenin Hills 1-3, Moscow 119991, Russian Federation.

Ilya Vladimirovich Lyagin. Senior Researcher. Candidate of Chemical Sciences.

Elena Nikolayevna Efremenko. Laboratory Chief. Doctor of Biological Sciences, Professor.

Contact information for all authors: 27nc_1@mil.ru

Contact person: Natalya Vasilyevna Zavyalova; 27nc_1@mil.ru 